\title{
Connecting corporations and communities: Towards a theory of social inclusive open innovation
}

\author{
Anil Gupta ${ }^{1 *}$, Anamika Dey $^{2,3}$ and Gurdeep Singh ${ }^{3}$
}

\author{
* Correspondence: \\ anilgb@gmail.com \\ ${ }^{1}$ SRISTI, GIAN, NIF \& IIMA, \\ Ahmedabad, Gujarat, India \\ Full list of author information is \\ available at the end of the article
}

\begin{abstract}
Despite pervasiveness of the market forces and supplementary role of the state and in some cases, even civil society organisations, there are unmet social needs which remain unaddressed by the existing institutions. With industrial growth becoming jobless, the need for new models of social innovation is being felt all around the world to provide jobs to the youth, skills for the new economy and entrepreneurial opportunities for transforming resources and skills. The persistence of some of these unmet needs (also referred as wicked problems sometimes) or unaddressed problems for a long time shows that the existing institutional arrangements are inadequate for the purpose. Innovations are imperative. A socio-ecological system that recognizes and rewards innovation can withstand many external shocks, provided it is agile and innovates quickly to remain responsive to emergent challenges (Anderies, Janssen, \& Ostrom. Ecology and society, 9(1)2004). Whether corporations will follow an open innovation approach to blend grassroots ideas and innovations with their expertise in a reciprocal, responsible and respectful manner (Gupta et al., Journal of Open Innovation: Technology, Market, and Complexity 2: 16, 2016) is still an open question. The design of appropriatemanufacturing and frugal supply chain will then become closely linked with other features of open innovation ecosystem. The debate on the role of social innovation in multi-stakeholder context in European focused on how these innovations fostered trust among different actors and influenced policy (Defourny and Nyssens. Social Enterprise Journal 4: 202-228, 2008).

In this paper, we describe the market and social forces which influence the emergence of social innovations through various processes. We then look into the evolutionary pathways for social innovations (Mulgan, Innovations 1: 145-162, 2006), to avoid inertia and spur initiatives to bridge the social gap in an inclusive manner through mobilization of youth in particular. The ecosystem for social open innovations provides scope for connecting corporations and communities (Herrera, 2015; Gibson-Graham and Roelvink, Social innovation for community economies: how, 2013). Following the theory of reciprocal and responsible open innovation systems (Gupta et al., Journal of Open Innovation: Technology, Market, and Complexity 2: 16, 2016), we explore the way barriers are overcome on the way to reach the base of economic pyramid [BOEP] customer. Technological adaptability and institutional or market adaptability are explored to understand how communities get empowered to deal with corporations through an open innovation platform. The corporations need to be empowered to understand the decision heuristics followed by grassroots and community frugal innovators (Gupta, Innovations 1: 49-66, 2006). Just as communities need to be empowered to negotiate fair and just exchange relationship with corporations (Honey Bee Network, 1990-2017).

(Continued on next page)
\end{abstract}


(Continued from previous page)

Finally, we conclude with the recommendations based on the experiences of grassroots

innovators that can enrich both social innovations and social enterprises following

commercial as well as social business models for meeting the unmet needs of the

disadvantage section of the society.

\section{Introduction}

Despite pervasiveness of the market forces and supplementary role of the state and in some cases, even civil society organisations, there are unmet social needs which remain unaddressed by the existing institutions. With industrial growth becoming jobless, the need for new models of social innovation is being felt all around the world to provide jobs to the youth, skills for the new economy and entrepreneurial opportunities for transforming resources and skills. The persistence of some of these unmet needs (also referred as wicked problems sometimes) or unaddressed problems for a long time shows that the existing institutional arrangements are inadequate for the purpose. Innovations are imperative. A socio-ecological system that recognizes and rewards innovation can withstand many external shocks, provided it is agile and innovates quickly to remain responsive to emergent challenges (Anderies, Janssen, \& Ostrom, 2004).

Whether corporations will follow an open innovation approach to blend grassroots ideas and innovations with their expertise in a reciprocal, responsible and respectful manner (Gupta et al. 2016) is still an open question. The design of appropriate manufacturing and frugal supply chain will then become closely linked with other features of open innovation ecosystem. The debate on the role of social innovation in multi-stakeholder context in European focused on how these innovations fostered trust among different actors and influenced policy (Defourny and Nyssens 2008).

In this paper, we describe the market and social forces which influence the emergence of social innovations through various processes. We then look into the evolutionary pathways for social innovations (Mulgan 2006), to avoid inertia and spur initiatives to bridge the social gap in an inclusive manner through mobilization of youth in particular. The ecosystem for social open innovations provides scope for connecting corporations and communities (Herrera, 2015; Gibson-Graham and Roelvink 2013). Following the theory of reciprocal and responsible open innovation systems (Gupta et al. 2016), we explore the way barriers are overcome on the way to reach the base of economic pyramid $[\mathrm{BOEP}]$ customer. Technological adaptability and institutional or market adaptability are explored to understand how communities get empowered to deal with corporations through an open innovation platform. The corporations need to be empowered to understand the decision heuristics followed by grassroots and community frugal innovators (Gupta 2006). Just as communities need to be empowered to negotiate fair and just exchange relationship with corporations (Honey Bee Network, 1990-2017).

Finally, we conclude with the recommendations based on the experiences of grassroots innovators that can enrich both social innovations and social enterprises following commercial as well as social business models for meeting the unmet needs of the disadvantage section of the society. 


\section{Part I}

\section{Theory of social innovation}

Social innovations emerge to meet the need unmet due to failure of markets, state and even civil society or augment, transform and restructure the existing ways of meeting $\mathrm{s}$ uch needs. Sometimes, technologies emerge which can be applied to deliver existing services better to meet the unmet or under-met needs of the disadvantaged section. Social innovations may involve several channels for serving the society such as social business/enterprise, social innovation based profit or non-profit enterprise, association, cooperative, groups or even individual social change agent. Sometimes, social innovations involve mobilizing people through new social movements. These movements may have a single or multiple locus of institutional core or anchor. The Honey Bee Network is a new social movement without any legal structure or boundary. But it has spawned several institutions such as Society for Research and Initiatives for Technologies and Institutions [SRISTI], Grassroots Innovation Augmentation Network [GIAN] and National Innovation Foundation [NIF] which provide institutional anchor to sustain the movement. It has also networked numerous other institutions, individuals and groups which may partly or wholly subscribe to the network philosophy in serving the society. Social networks play a very critical role in evolution, testing, diffusion and further modification of social innovations (Moore and Westely 2011, Chalmers 2013).

The social business can be defined as an economic activity addressing an unmet need of the disadvantaged people or making an existing delivery system more efficient, effective and accountable to different stakeholders including the people to be supported. Social business can have profit or non-profit purpose but its goal is not profit maximization (Yunus 2010). In the case of profit-oriented enterprise, a large part of the profit goes back to the people. Amul Dairy Cooperative movement is able to give back more than $80 \%$ of the value of the milk provided by the farmers to them as payment. In the $20 \%$ margin, it manages the entire supply chain, logistics and other manufacturing infrastructure. Incidentally. Amul is th ebigegst brand of India worth 30,000 cr rupees (USD 5000 mill). A business may share entire surplus with the people involved in the provision of raw material and/or consumption of the final product and service, as is the case with many cooperatives. Such businesses may or may not grow very far depending upon the resources they set aside for replacing the infrastructure [depreciation], skill development and enhancement of capabilities of staff as well as customers, R\&D, innovations for designing new products and services to expand market and serve existing clients more empathetically. Social business can be evaluated on the parameter of inclusiveness. There are six kinds of exclusion which a social business or an enterprise should try to overcome completely or substantially. Every social enterprise/innovation/business must serve the people in relatively inaccessible areas, engaged in neglected sectors, having skills for which market has come down or doesn't exist, suffer from seasonal or temporal exclusion and belong to social classes which have historically remained suppressed, bypassed, exploited and underserved and governed by structures which give priority to serve the poor. If social, sectoral, seasonal, spatial, structural and skill-based exclusion is not overcome, then an enterprise is not inclusive or inclusive enough. Existing corporations may not have inclusivity in all their functions. They may not hire sufficient women or staff from neglected social classes. But, they may serve them better than others. It may not always possible to have inclusivity in all functions and all services and yet such inclusion is desirable. For example, a social 
health enterprise may not have medical doctors coming from tribal or scheduled caste background and yet it may serve the most neglected people in the most affordable and accessible manner. The medicine may be affordable but manufactured by Multi-National Corporations and not small distributed businesses.

The design of institutional platforms that reduce or eliminate the ex ante and ex poste transaction costs of product and service providers and users in a given situation of social inequity may depend on the degree of openness for mutual learning between formal and informal sectors existing in the eco-system. Higher the openness, greater may be the flexibility in designing open innovation platform. The conventional framework of open innovation has referred to corporate willingness to learn from outside but less often about the extent to which a corporation shares its knowledge with outsiders. The central tenet of the Honey Bee Network has been openness in sharing, learning and valorizing people's knowledge through cross pollination and linkage with formal science and technology, business and financial sectors.

Many farmers and artisans share their innovations openly without caring about the possible revenue they could have generated by keeping it confidential or restricted. A concept of technology commons was developed to ensure that despite IPR protection, people to people sharing is allowed and encouraged. However, the grassroots innovations can be accessed by a commercial company only through license (Sinha 2008, Gupta 2012. This is a hybrid version of open and close system of innovation. Generally, most grassroots innovators benefit from the feedback they get from the community members including users and non-users of their innovations. In some of the open innovation communities in formal sector, similar values exist.

There has been a long debate about the difference between social innovation, social enterprise and social business. The social innovation is a creative and compassionate solution for an unmet need of a disadvantaged social segment so far excluded from the benefits of development. It is not necessary that the solution may emerge only from the people who are affected by the problem. When it does, it becomes an example of social innovation from grassroots. When it is developed by outsiders such as a corporation or a public sector agency or a voluntary organisation, it becomes innovation for grassroots. One can also have social innovations emerging at grassroots though with or without involvement of people as designers and/or users or both. When such solutions have to be provided to several communities on an ongoing basis, one needs an operational, logistical supply chain. Such manufacturing and supply of solutions may take place on commercial basis or not for profit basis. It can also happen that moderate profits are generated but not shared with the promoters as applicable in section 8 companies or what Prof. Yunus calls as social business. The programmed development and delivery of goods and services at the door of needy communities with or without full cost recovery is called social enterprise. The line between social innovation and enterprise is fuzzy. Once an activity acquires an entrepreneurial propulsion backed up by a budget and a revenue recovery system, it acquires an enterprise format. The cost of services or products may be met by third party or through CSR funds, through crowd funding or endogenously by the community itself [Fig. 1].

The emergence of social innovations in any society indicates that some of the unmet social needs have spurred experimentation for searching a solution. Market failure occurs when the cost at which solution is available is beyond the reach of majority of those who need the solution. The state failure takes place when public policy either 


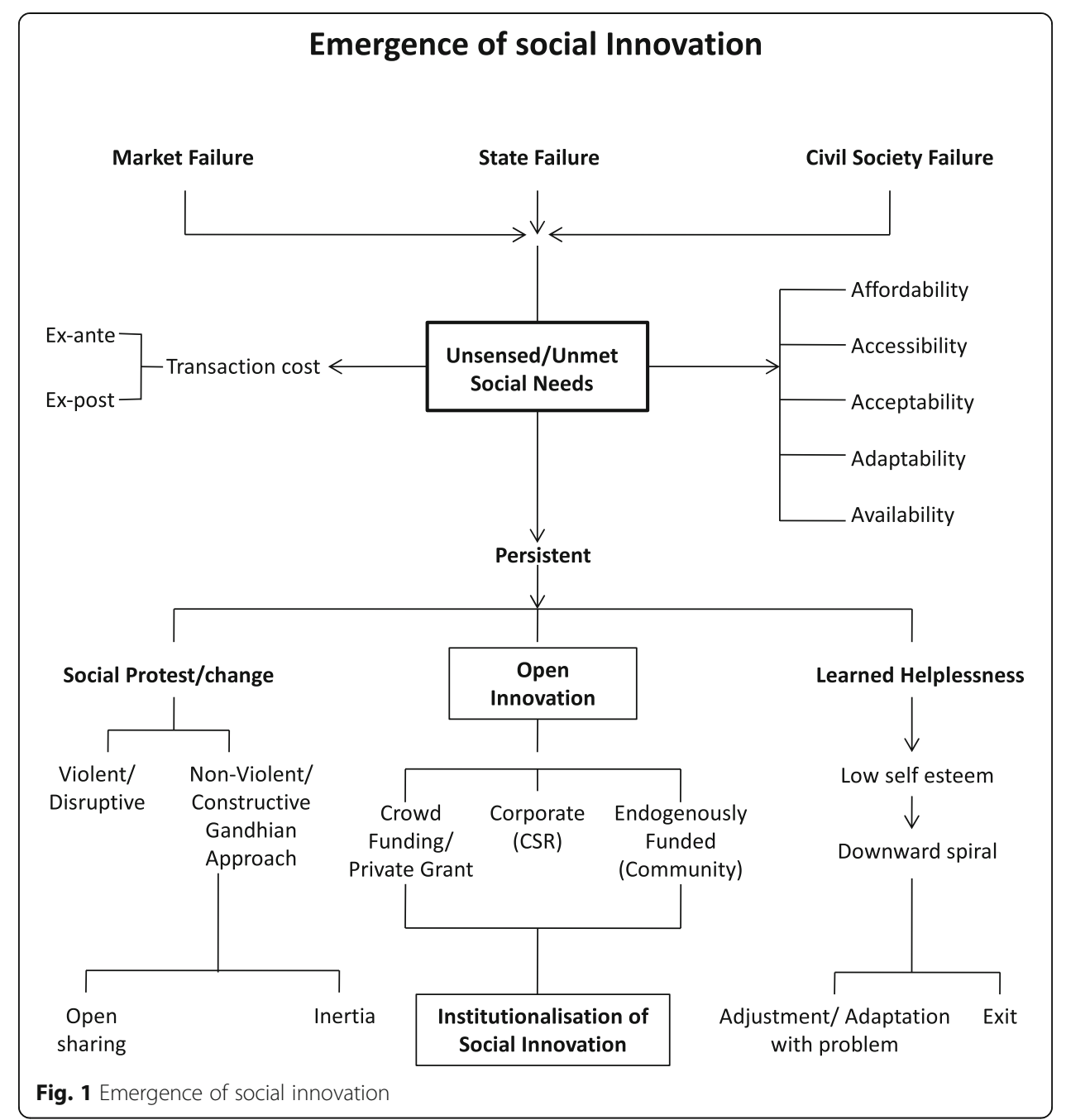

does not target the most affected people or uses indicators which do not ensure that the most needy benefit from existing delivery systems. Civil society failure happens when even the voluntary organisations find it either infeasible or lack resources to reach the unreached social segments. In such a situation, some of the affected people or other individuals may develop an accessible, affordable, adaptable solution available to the most needy ones. If these initiatives are converted into innovation through open learning and open sharing, then social innovation also becomes an open innovation. Sustainability of such solutions depends upon the degree of reciprocity among provider, consumer and facilitator of the delivery systems. To illustrate, in many of the semi-arid regions with limited irrigation potential, high climatic fluctuation, markets are often weak because of poor infrastructure. Even the public systems are weak because often the state uses such locations as punishment postings for laggard officials. Since neither the bureaucratic system nor the political system is much inclined to serve the interests of such people, the instances of apathy and inadequacy are rampant. In one such case, during our learning walks, Shodhyatra, we came across a practice for pest control which are very sustainable and extremely affordable. The problem of termite attack in wheat in drylands is quite pervasive. Most farmers being poor, cannot afford chemical 
pesticides which are also not very effective in such cases. The private sector agencies and public sector scientists have not paid adequate attention. A farmer shared a very interesting and extremely affordable solution. He mentioned that while irrigating the wheat crop, they put cut pieces of cactus like Euphorbia or Opuntia in the irrigation channel. The latex of these cacti dissolves in the water and spreads in the field to help control termites. This is an open innovation socially extremely useful and affordable by the poorest people and developed also by the poor people.

\section{Social innovation by women: a case study of recipe competitions}

We conduct recipe competitions during the Shodhyatras to celebrate local culinary creativity and innovation as a social innovation. Women use their knowledge of edible and therapeutic weeds or companion plants (weeding is mostly done by women), waste from fruit and vegetables like the pericarp, etc. Tables 1 and 2 lists uses of weeds reported in three villages of eastern Uttar Pradesh (Dey, Singh and Gupta, 2015 Women share their knowledge and innovations in open, beyond the caste, class or other boundaries. This helps them to effectively cope with the stress period in the households. It was recommended that to strengthen the agency/aability of women, we need platforms like The Honey Bee Network where peer group exchange of knowledge and expertise is encourage and facilitated. Such institutions will also maintain an open database of such knowledge which can be recalled, retrieved and redistributed whenever needed. It has to be in a media and language with which the women in the region are comfortable and conversant. "The knowledge transfer across generations, particularly among women is vital for maintaining sustainability quest of vulnerable communities." (Dey, Singh and Gupta, 2015).

\section{Social Innovation and community resilience}

In addition to the examples of open exchange of knowledge, expertise and resources decribed in Tables 3 and 1, there are many other examples in the Honey Bee Network [honeybee.org, Sristi.org] of indigenous knowledge and innovation which impart resilience to the communities. Harbhajan Singh, a small farmer from Hisar decided to irrigate cotton field in alternate rows. The water requirement went down by half. The pests attack also got reduced because of less succulence in the plant. The pesticide cost and its adverse environmental effects also got reduced. The challenge in diffusing such social innovations really is that the user cannot be expected to pay for such open source information. Therefore, third party agency has to bear the cost of diffusion. When social entrepreneurs and innovators fail to mobilise resources either through crowd funding or subsidies/grants, such extremely affordable and democratic sustainable innovations fail to diffuse. The process of development then does not become inclusive enough.

Insistence on full or partial payment by users for such knowledge, practices or sometimes even tangible solutions [such as low cost devices for physically challenged people] may lead to exclusion of the most needy and the poorest ones. In this paper, we have argued for a framework that reduces transaction costs on supply and demand side and make such intermediation possible that needs of the most disadvantaged people don't remain unmet. The way institutions are designed and monitored, it is becoming more 


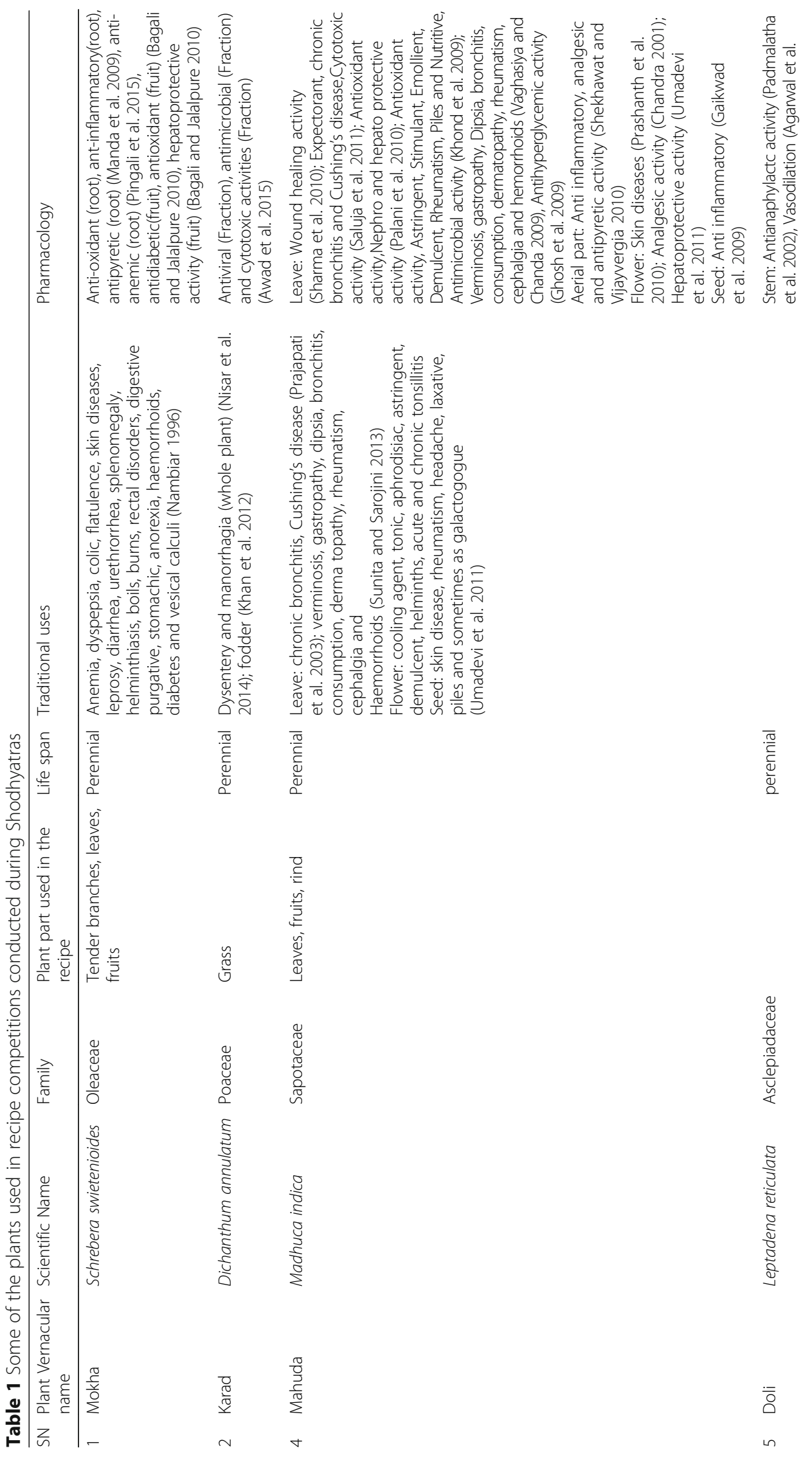




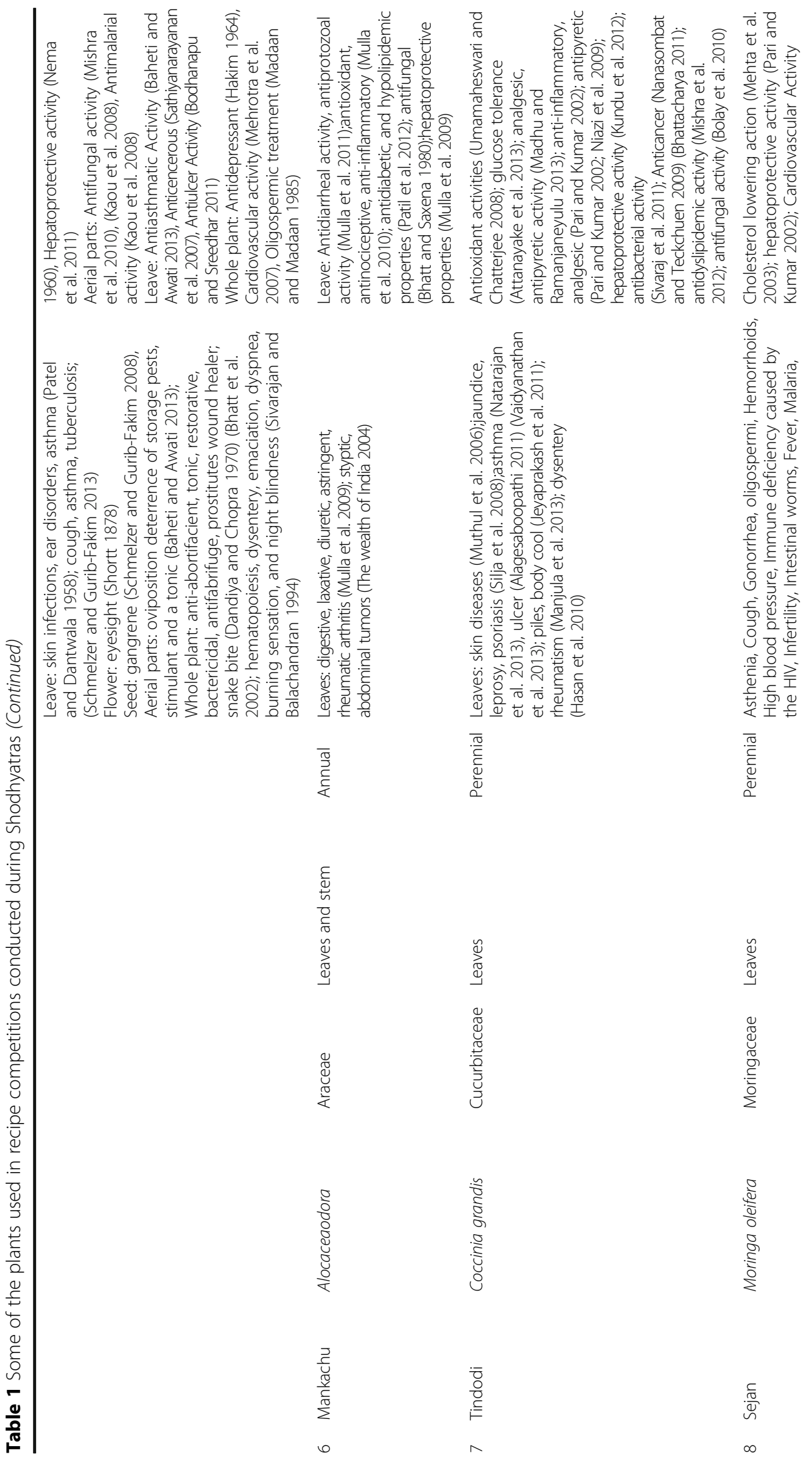




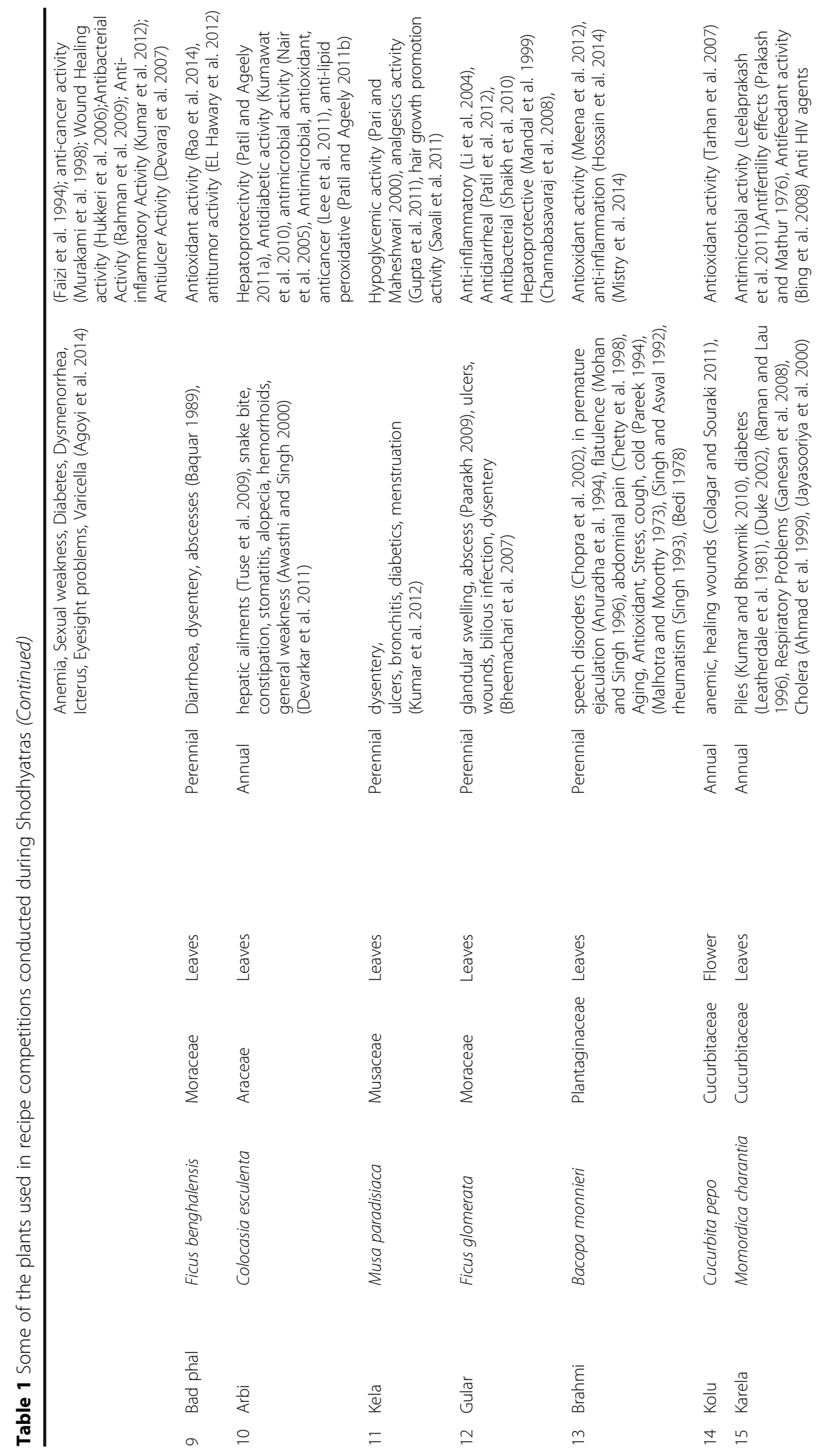




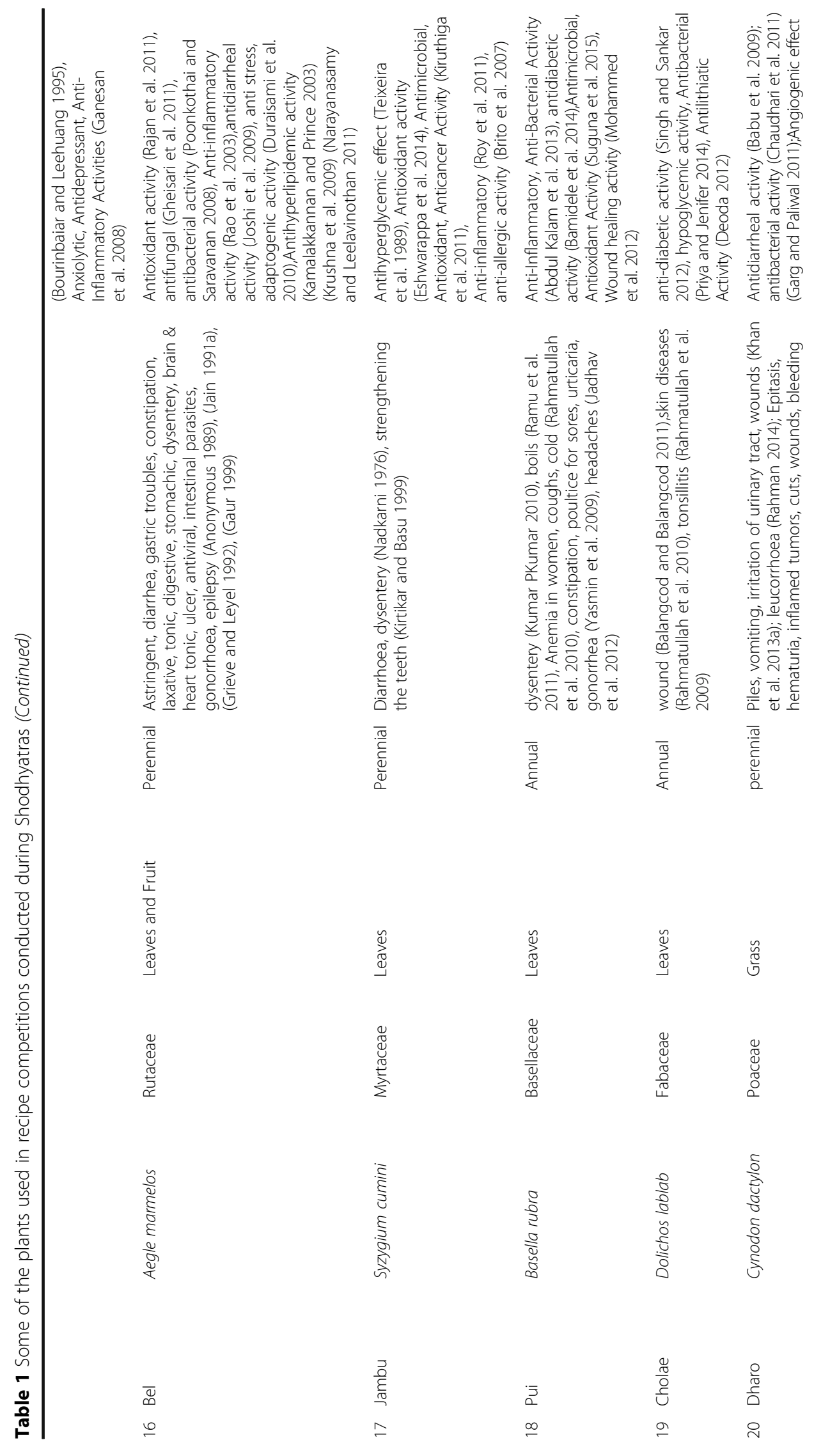




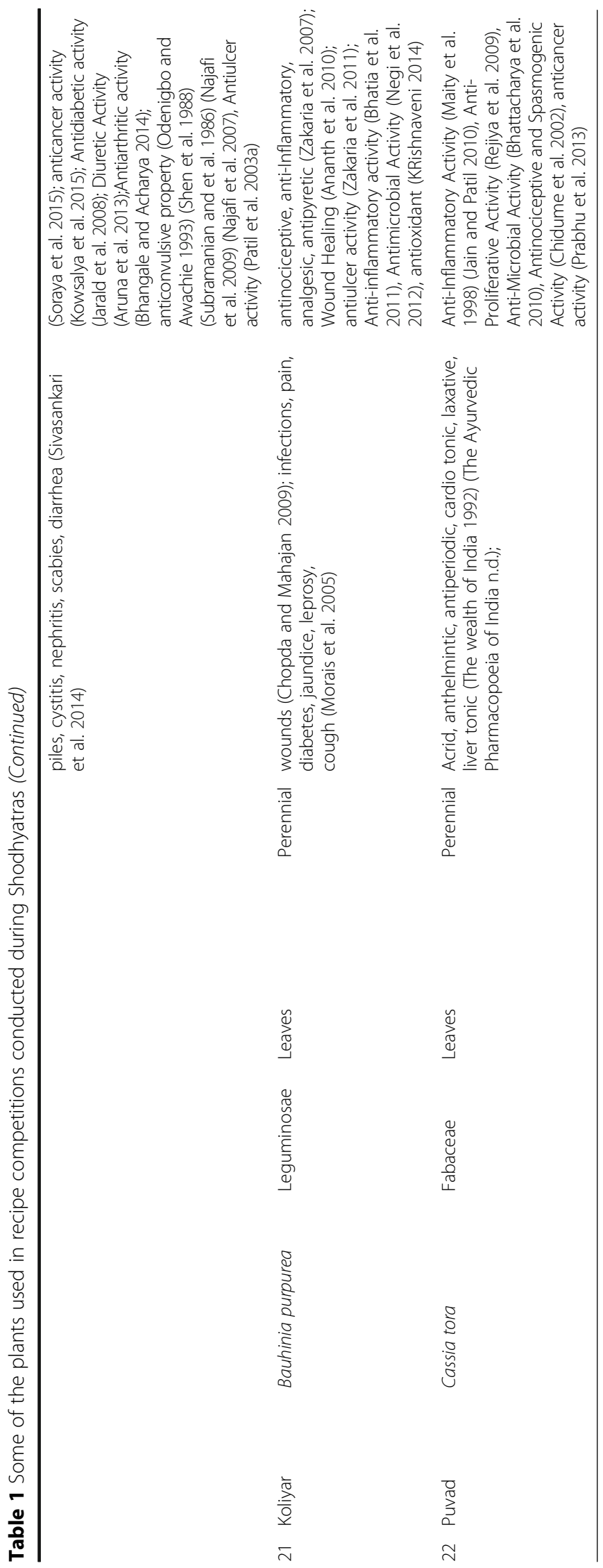




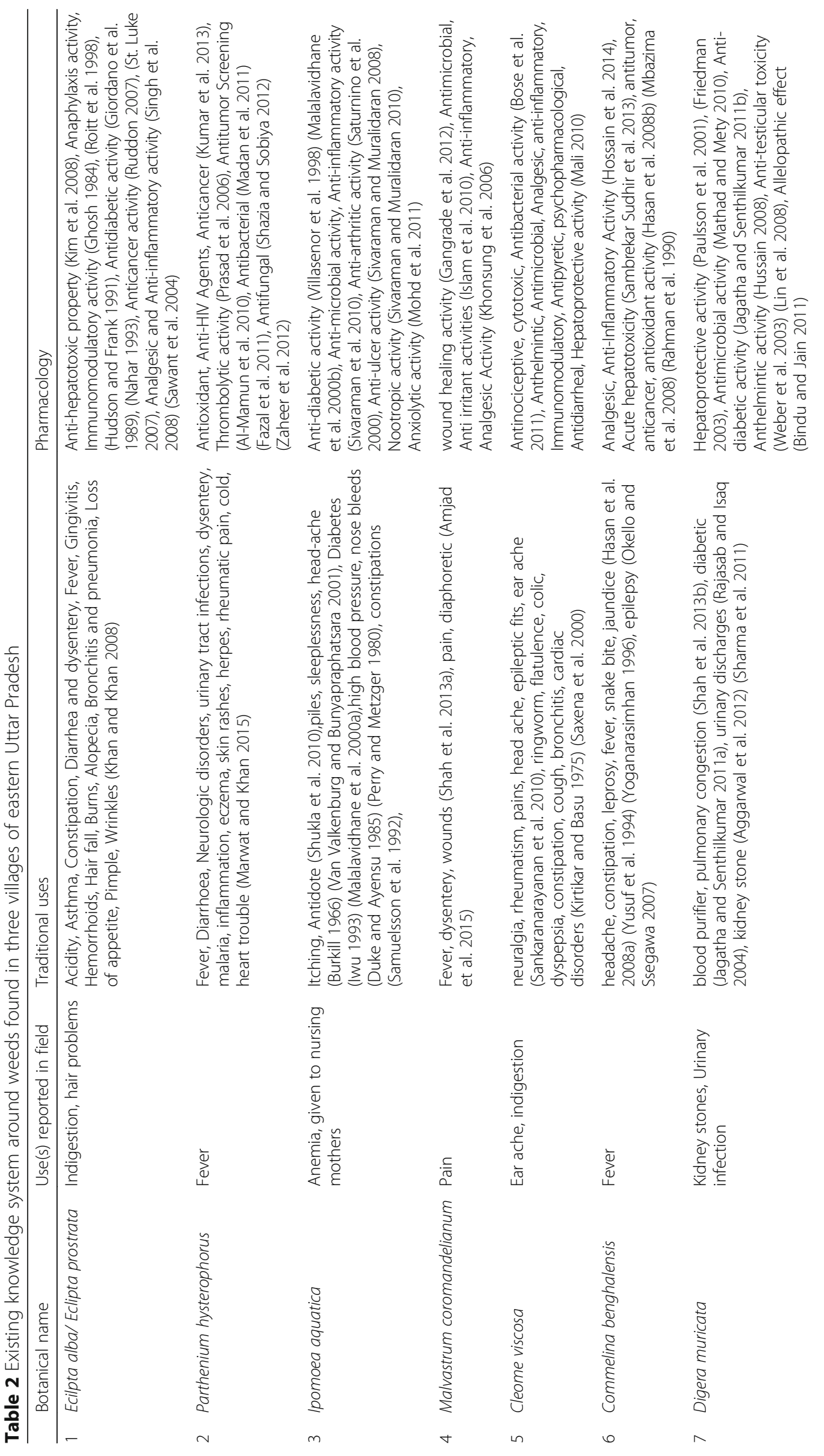




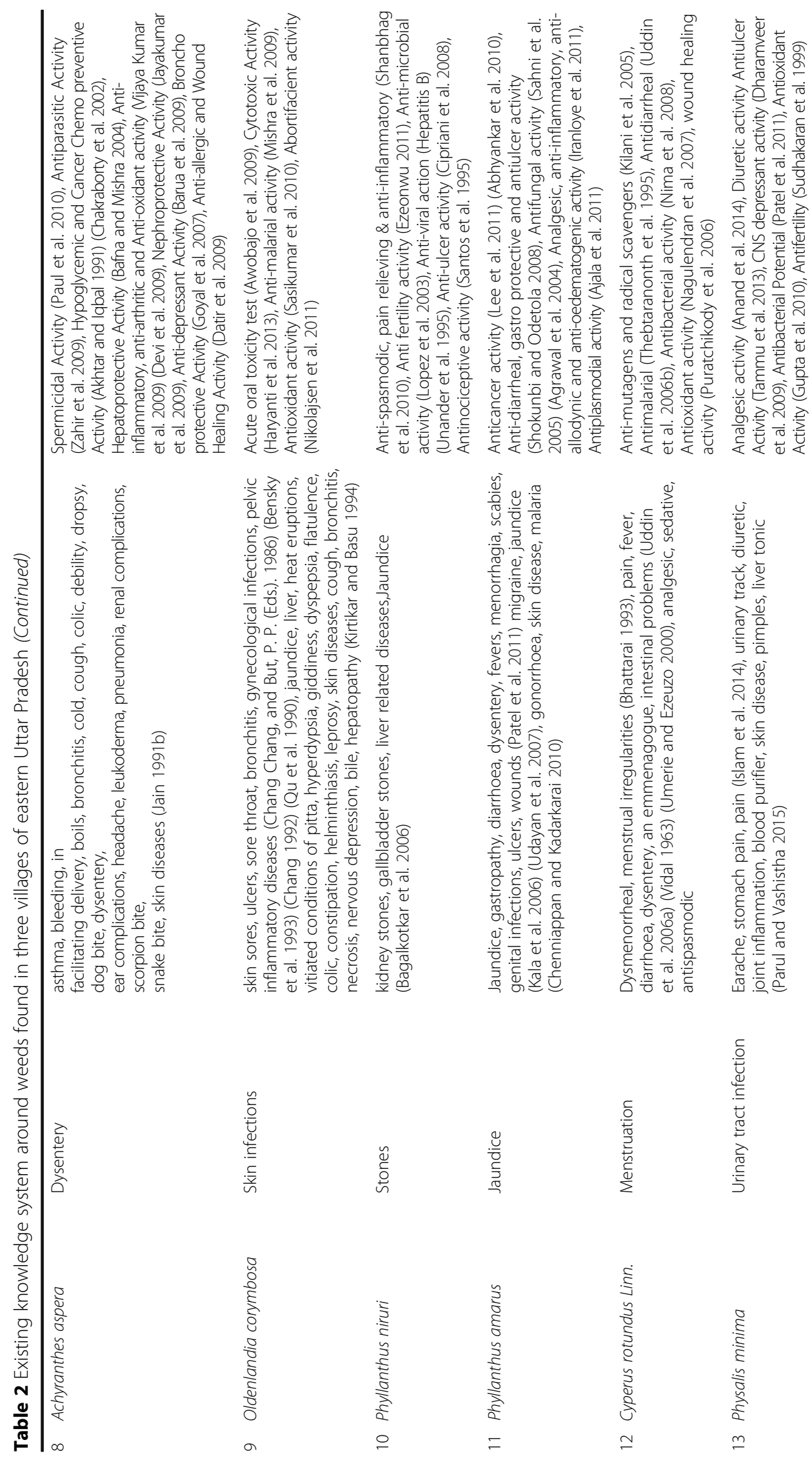




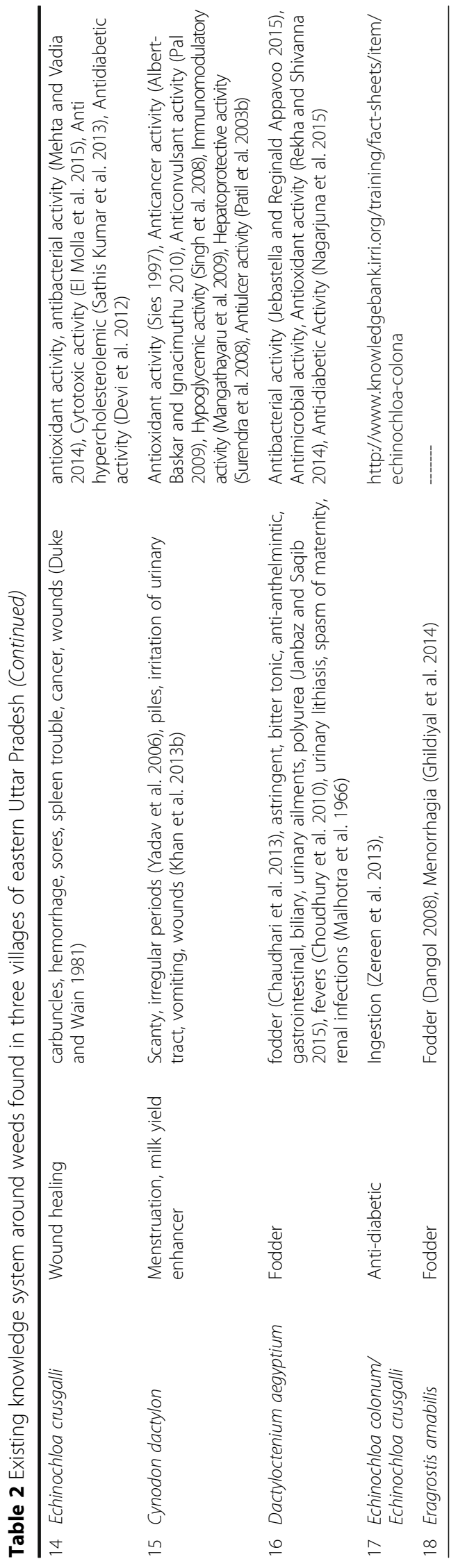


Table 3 Taxonomy of social innovation approaches (six Bs of basic design approaches) ${ }^{a}$

- Bridging function: Bridging function implies meeting need gaps by linking the available actors supplying innovative solutions with needy communities. The existing suppliers may even design new solutions after bridges are formed if the need be, with or without participation of users.

There are several ways in which bridges are formed among different actors meeting the unmet social needs. Bringing actors together, creating platforms for sharing information and generating mutuality of interest and help in forging bridges. Many online match making platforms provide information of various actors who can on their own form association or partnership. Enabling a two-way flow of information may not be sufficient for forming bridges in every case but it increases the possibility given the willingness among the actors. A platform of voluntary organisations working for the blind and various agencies providing content, technologies, funding, etc., may trigger partnerships. Bridge function is one of the weakest process but a very popular one.

- Broker: Broker reduces the ex-ante and ex-poste transaction costs of the social innovators/entrepreneurs \& meets the unmet social needs at mutually agreed terms.

Brokers not only bring the actors together but also mediate the deals. Thus, in the above case the agencies working for the blind may not be able to develop proposals, fulfil all the guidelines or generate enough funds to avail of innovative solutions or other support system. Social innovators involved in brokering will reduce transaction cost and create mutuality of interest. Generally, brokers also take responsibility for due diligence which the bridge function may not do.

- Benevolence: A philanthropic or charitable operation under which uniform solutions are offered to the affected people presumably meeting their similar unmet needs. The fit between supply and demand may be optimal or suboptimal depending upon the inherent nature of diversity and variability among users.

The charitable organisations may provide uniform solutions or in some cases may agree to adaptation of the solutions for meeting the needs of the user organisations. The benevolent organisations provide bridge and broker the deal and fund it to make sure that needs are met. Sustainability of such platforms or processes may depend upon the continued willingness of benevolent social innovators to underwrite the costs of meeting the unmet needs.

- Social Business: Where a commercial and/or not-for-profit organisation provides a business opportunity to people to meet their own needs or through third party enterprise with or without recovery of full cost of doing so. Social business enterprise can meet partly or fully the unmet needs of the users. There can also be differential pricing of products/services, which may enable their cross subsidization to the consumers.

In this model of social innovation, the mediating organisations enable entrepreneurial approaches for meeting the unmet needs. The social entrepreneurs may cover fully or partly the costs of providing products and services. Whether such a system will sustain depends upon the viability of the business plan or ability of the user organisation to cross subsidize different classes of users to run the activity. There are cases when the intermediating organisations provide business solutions but the costs are met by some philanthropists till such an organisation becomes self-reliant.

- Bonding: Social innovation may bring about evolution of common property/pool institutions and/or organisations by bonding communities \& harnessing their social capital to meet their needs. Bonding can have implications for the way companies or institutional resources are mobilized or generated locally. These institutions can be autopoeitic that self-design and self- governed; or hetropoeitic or PPPP (Public-PrivatePeople-Partnership) in nature (Dey, Singh and Gupta, 2017).

Social innovators in such cases invest their energy in creating community organisations or fostering social contracts so that with or without outside support, the needs of the disadvantaged sections are met. When differently abled children attend the regular schools, the intervening agencies or social innovators try to make the sighted students take responsibility of the blind ones. The differently abled children learn to share their strengths and seek help when necessary without feeling obliged or patronized. One can have a variety of institutional arrangements for creating social bonds to empower committees to meet their needs autopoeitically or hetropoeitically.

- Bundling \& Blending: Bundling approach to social innovation implies creating a bundle or a combination package of existing component solutions or sourcing additional components available locally or externally or both to meet the unmet social need. The users have a choice in some cases to make or modify their own bundle to suit their needs with in their affordability constraints. Blending approach to social innovation implies re-configuring different components in a manner that the user cannot separate one component from the other. In this case the user has to take all of it or leave it. It cannot modify the blend except through appeal to the provider of blended solution to modify its offering in due course.

Both in product and service innovations, a wide scope exists for bundling and blending the variety of solutions so as to suit the needs of users. The bundling approach in the case of blind students would mean access to braille books, audio books, various devices for navigation and other services. Depending upon individual preferences one can choose to have all or a combination of some of them to improve affordability and flexibility. In the case of blending, one cannot separate different functions or features. Even if one is likely to use only two out of five features, one has to pay for all five. The re-configuration may not be possible either due to technological constraints or institutional ones.

It is not necessary that all these approaches occur in mutually exclusive manner. Either over time, i.e., sequentially or over space the functional integration can be facilitated to meet the unmet user needs. Empowerment of the communities meeting their needs through external provisioning may require institution building by the social innovators. This is one area where even corporations or communities are unable to invest long term resources to create capacity among the user community for negotiating appropriate terms of 
Table 3 Taxonomy of social innovation approaches (six Bs of basic design approaches) ${ }^{a}$ (Continued)

exchange under various functions described here. The reciprocity and mutual accountability in social innovations requires reliance on inclusive open innovation so that all the parties share and seek ideas without reservation or restrictions.

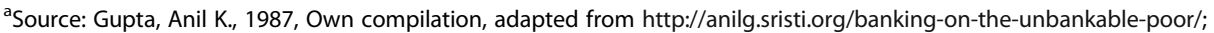
Gupta Anil K., 1987, Being Bridges, Brokers or Benevolent Banias, CMA, IIM., Ahmedabad; Gupta Anil K., 1987, Banking in Backward Regions: Banks-NGO-Poor Interface -Alternatives for Action, IIM Working Paper No.675, in Indian Journal of Public Administration, Vol.XXXIII (3) Nos. 662-679, July-September 1987

and more difficult even by public institutions to serve the extreme cases of public interest. Limits of market, state and civil society are seldom brought to the heart of popular discourse. But such limitations are not inherent in a capitalistic system (Yun, 2017). The open Innovation conference by SOITCM (Riga, 2017) is actually aimed at transcending such limits.

\section{Emergence of social innovation (Fig. 2)}

There are several reasons why needs of some of the social segments remain either unnoticed/unsensed or if noted, remain unmet. The failure of markets, state or even civil society may cause such gaps in meeting the needs persist for a long time. The transaction costs of meeting such needs may be high due to terrain, basic infrastructure, lack of local demand or a combination of other technological, cultural or institutional factors. There are five A's which explain why needs may remain unmet even if some of the transaction costs are met. The solutions may not be affordable or accessible or even acceptable. It is not enough to have acceptable solutions because needs may change over time and the change may not be uniform for different community members. In such cases, the adaptability of solution and its availability becomes important parameter for supply chain management. What use an affordable, acceptable and accessible solution is, if it is not available. Certain needs therefore remain unmet for long time though policy makers or corporations may claim that they have solutions for the same. Suitable interface among natural, social, ethical and intellectual capital helps in overcoming transaction costs (Gupta et al., Gupta et al. 2003, Gupta 2006).

There are several ways in which the community members try to articulate their need. They may protest through violent or non-violent means and if policy doesn't change, the inertia may follow. This may aggravate the frustration and in extreme cases, may give rise to insurgency. The non-violent constructive Gandhian approach may lead to co-creation of solutions through joint action between people and the formal institutions (Guha 2006). People learn to be helpless sometimes. Their self-esteem goes down and the downward spiral of low esteem, low aspirations and low expectation leads to other adjustment with whatever problem exists or may trigger exit through migration or abandonment of the enterprise.

The most hopeful scenario which has been the foundation of the Honey Bee Network is innovation at the grassroots level (Gupta 2013, 2006). These innovations may be supported endogenously by individual innovator or his community, through crowd funding of private or public grants and in rare cases through corporate social responsibility. The open innovation framework may trigger institutionalization of social innovation if the needs are met adequately and the communities and/or 


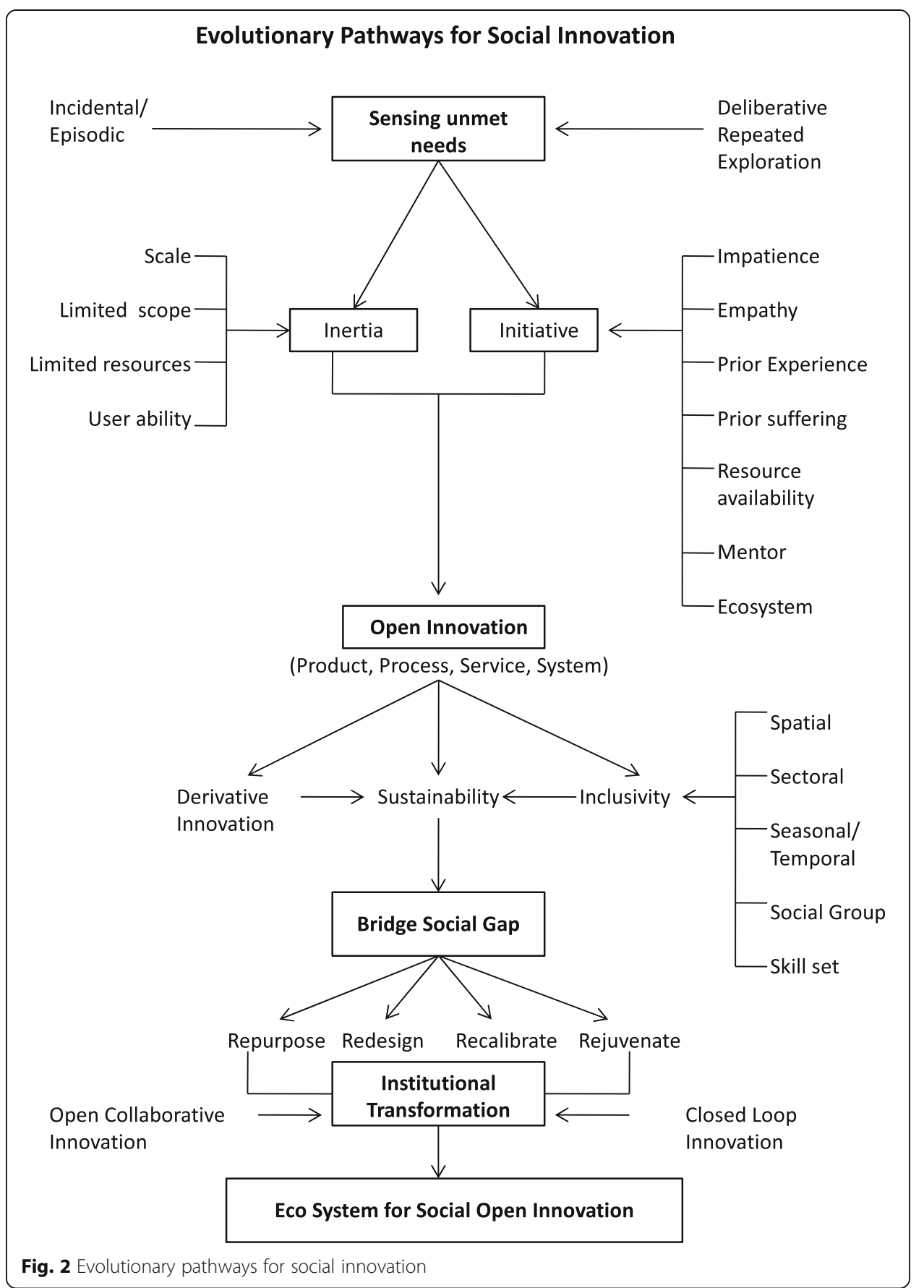

individuals try to improve the ideas on their own. Grassroots innovations provide an opportunity for engagement to not only corporations but also high net worth individuals and any other person who wishes to contribute small amounts through crowd funding.

In the figure two, evolutionary pathways for social innovation are described. Either through some extreme event, accident or otherwise, one may sense the unmet need. Deliberate attempt to study the reasons for unmet needs may also uncover them. If the institutions responsible for meeting the needs are overawed by the scale of 
the problem, limited scope of their mandate, inadequate resources or inability of users to use what is available, the inertia may follow (Geels 2004). But, if either some individuals or community feels impatient, empathetic, or has prior experience of solving problems, it may take initiative (Smith and Tushman 2005). Availability of resources, mentors and ecosystem support may also reinforce the willingness to take initiative. The initiatives may emerge endogenously or exogenously [Fig. 2]. They may or may not evolve into an innovative solution. Various facilitative or inhibitory factors may influence this transition. Sustainability of social innovations may depend upon the openness of the learning and exchange platform. Product and process innovations may be accompanied by service and system support by third party agencies or individuals. In a dynamic social situation, neither need remain constant nor the design or delivery system. Continuous derivative innovations are necessary including by the bypassed communities.

The interplay between inertia and initiative may lead to innovation in product, process, service and system including the excluded regions, communities, sectors, skills or other factors. Continuous improvements and inclusivity may contribute to sustainability in bridging social gap. Whether the solutions so generated require repurposing available institutions or technologies, redesigning them, recalibrating them or rejuvenating them depends upon how institutions transform themselves for bridging the social gap. The corporations may also develop inertia and thus may not take initiative to generate social innovations. Small enterprises, communities may also remain timid and limited in their vision without exploring open innovation to learn and share their approach to solving problem. It is true that grassroots innovators follow open innovation far more than large corporations. For every one Tesla which opened all its patents, there are tens of thousands of farmers, mechanics, labourers, artisans, etc., who share their solutions to meet the social gap openly.

The ecosystem for social innovation may however need both the community level initiatives but also corporate contributions beside public policy support. Both closed loop innovations and open collaborative innovation have a role to play in institutional transformation. The design of a mobile phone is a closed loop innovation backed by hundreds of patents. But it also provides open platforms on which different factors can design participative and open access knowledge base and communities. Institutional transformation may involve repurposing the existing institutions or sometimes redesigning. When that is not easy to accomplish recalibrating the monitoring indicators and success factors may become necessary to rejuvenate the institutions. The ecosystem of social innovation does not grow only through transformation of existing institutions. There are situations in which disruption of established norms and values become necessary to achieve the larger social good so long as the core values of reaching the unreached remain intact. The classical banking model, trying to serve rural communities through branch network left almost $40 \%$ people of our country unbanked. New payment gateways and channels have made banking accessible to the most remote corners of the country which had not been reached through conventional model. More innovations are called for to incorporate the barter economy still prevalent in tribal areas. The strength of the ecosystem lies in constant recalibration of indicators of performance. More and more difficult 
problems must occupy the agenda for action with change in social norms of sensitivity and accountability.

\section{Corporations and communities: mutual empowerment (Fig. 3)}

Corporations have been trying to reach the base of the economic pyramid ${ }^{1}$ by providing flexibility at institutional or market level or in the design of technological solutions. Corporations have succeeded in delivering small sachets of cosmetics, tea or coffee to millions of villages. And yet, the open source multimedia, multilingual content for educating children has not reached even a few thousands village schools (Gupta et al. 2000). The supply change efficiency in delivering consumption goods fails to mimic similar efficiency in overcoming anemia among $60 \%$ women. Several factors have been discussed earlier responsible for neglect of unmet needs. Corporations need to be empowered to bring in flexibility and adaptability in their technological and institutional functioning. Their ability to develop frugal designs would increase when corporate designers will work with grassroots innovators to learn from their heuristics. Not all designs are modifiable or are climate resilient, environment friendly or gender neutral. But greater connect with the community might develop

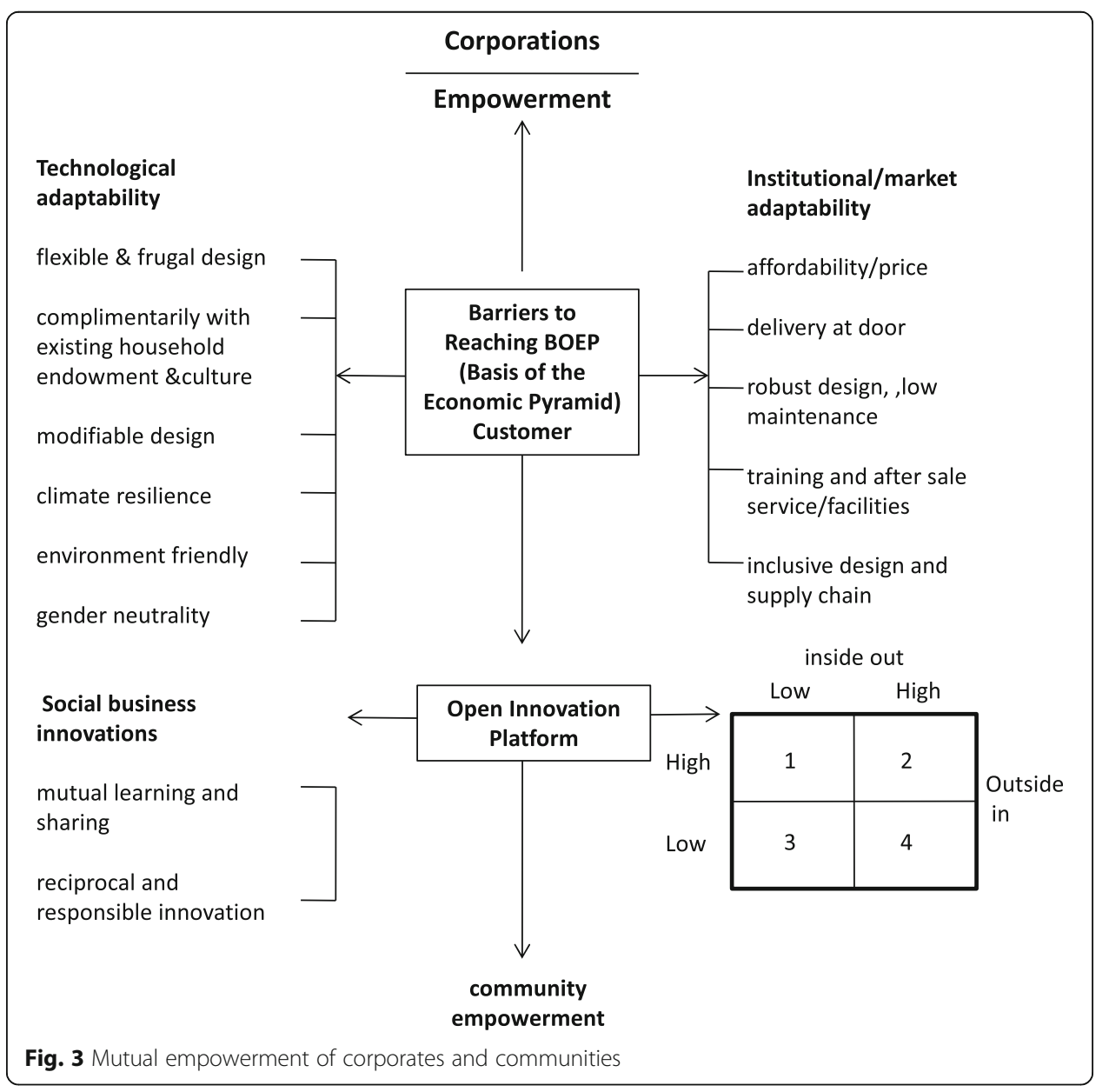


empathy and a reciprocal and responsible innovation system may evolve. Amul cooperative model has demonstrated that scale need not prevent close affinity with client's interest. Amul transfers more than $80 \%$ of the value of marketed milk products to the milk producers. With almost 30,000 $\mathrm{Cr}$ worth brand, it has shown that a completely inclusive service model can be built to provide comprehensive care for household livestock enterprises.

The open innovation platform bringing corporations and communities together to generate, adapt and deliver social innovations can have four possible approaches. Openness is measured here in terms of willingness to share one's knowledge and resources with others that is inside out; and the opposite that is desire to learn from others i.e. outside in. The most indifferent and pessimistic situation is (cell1) when both inside out and outside in are low [Fig. 3]. Such organizations do not want to share with other organizations or the communities what they are good at. Nor do they want to learn from them. It is ostrich kind of behavior which will not lead to much reciprocity or responsibility between corporations and communities. In the second case, the inside out is high and outside in is low. Such ecosystems of organizations encourage pollination of ideas, open sharing of their knowledge as done by Tesla. This pioneering company in electrical cars opened all its patents to encourage competition and installation of more charging stations for customer convenience. Those who have high outside in and low inside out [cell 3] behave like a sponge seeking ideas from others but not sharing much with them. Many large corporations crowd source ideas from outside for frugal and/or social innovations with or without payment. They seldom give feedback to the idea providers as to what did they do with the ideas received and value generated. If they will let idea providers know, how valuable those ideas were, their confidence in their own innovative potential could increase manifold.

The reciprocities between corporations and communities can be pursued through several mechanisms with or without intermediation of third party.

a) While sourcing ideas, even if corporations don't use these ideas as such but these ideas trigger further investigation, they should acknowledge the idea provider and share some benefits with them. Without their initial trigger, the corporations may not have reached the point they actually reached. A very large industrial house and a national research lab jointly found a lead of developing graphene kind of material from natural resource very useful and interesting. Their representatives even visited the tribal community which provided the original lead. Eventually, through R\&D they developed a process which could make a graphene compound providing a lot of potential for commercial advantage. They refused to acknowledge either the community or National Innovation Foundation [NIF] which mediated in the exchange and facilitated their visit in good faith. The patent was filed without any attribution to the Foundation and the tribal community, the question of sharing benefits didn't arise. The Foundation is opposing the patent on various grounds and deeply regrets an unethical behavior on the part of the formal institutions in this regard. The capacity of this Corporation and the concerned national $\mathrm{R}$ and $\mathrm{D}$ lab needs 
to be improved so as to deal with generosity of knowledge rich, economically poor community with a sense of reciprocity and responsibility.

b) The mutual capacity building among corporation, community and civil society organizations are required when each fo the actor fails to appreciate constraints and strength of other partners.

c) The corporations learn the art of frugal innovations from grassroots innovators and youth and share the art of frugal supply chain with the communities.

d) The generosity of communities may sometime motivate the corporate executives to take time off and extend their personal social capital in aid of social innovators.

e) Social innovations need not be sustained only through profit based social businesses but can also rely on open source do-it-yourself culture or third party subsidization of the cost of providing services.

f) The involvement of youth and children in social innovation movement can prove very helpful since they have much less inertia than elderly people.

g) one can hybridize patent system with open source system through the concepts like Tech Commons.

There are numerous ways in which social innovations are nurtured and mutually rewarding relationships can be forged among corporations, communities and civils society organizations. What matters is not only the mutual reciprocity and responsibility but also willingness to learn from each other, build each other's capacity and have graciousness to realise that creative, frugal innovations may emerge from even informal sector, children and bypassed communities.

\section{Endnotes}

${ }^{1}$ There are several pyramids. People at the bottom of the economic pyramid may not be at the base of ethical or innovation pyramid contrary to what Prahald (Prahalad 2006) has argued.

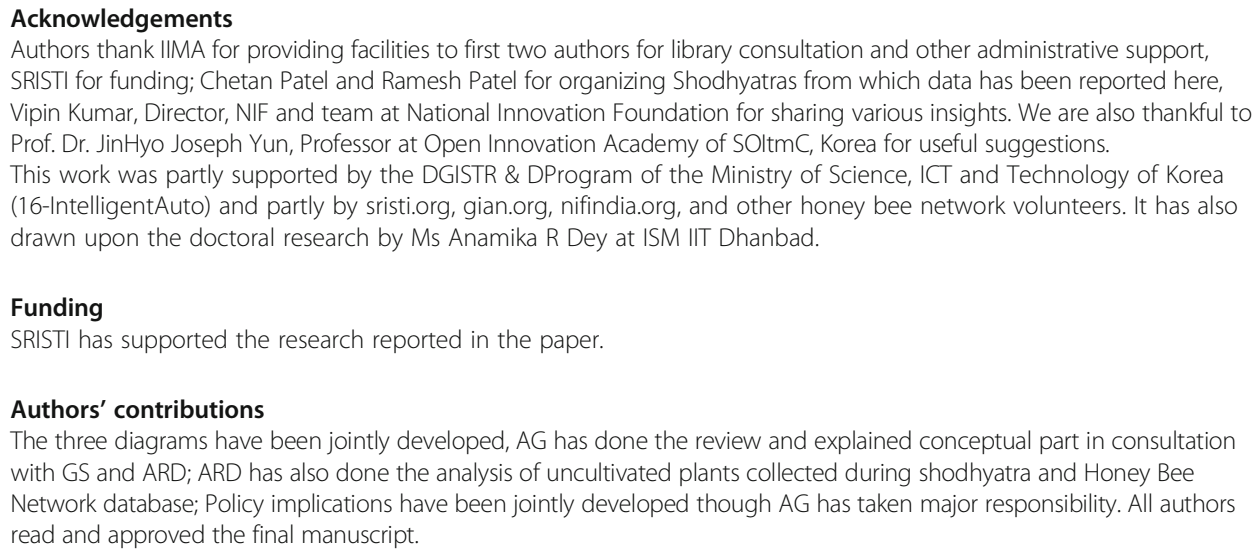


Author details

${ }^{1}$ SRISTI, GIAN, NIF \& IIMA, Ahmedabad, Gujarat, India. ${ }^{2}$ AASTIIK, SRISTI, IIMA, Ahmedabad Gujarat, India. ${ }^{3}$ IIT ISM, Dhanbad, Jharkhand, India.

Received: 12 June 2017 Accepted: 6 July 2017

Published online: 21 September 2017

\section{References}

Abdul Kalam, A., Sulaiman, W., Azizi, W. M., Labu, Z. K., \& Zabin, S. (2013). An overview on phytochemical, anti-inflammatory and anti-bacterial activity of basellaalba leaves extract. Middle-East Journal of Scientific Research, 14(5), 650-655. ISSN: 1990-9233. Accessed at http://irep.iium.edu.my/30539/1/Azad_MEJSR-Bsella_ alba.pdf

Abhyankar, G., Suprasanna, P., Pandey, B. N., Mishra, K. P., Rao, K. V., \& Reddy, V. D. (2010). Hairy root extract of Phyllanthus amarus induces apoptotic cell death in human breast cancer cells. Innovative Food Science \& Emerging Technologies, 11(3), 526-532. doi:10.1016/j.ifset.2010.02.005.

Agarwal, S. L., Deshmankar, B. S., Verma, C. L., \& Saxena, S. P. (1960). Studies on Leptadenia reticulata, part I: pharmacological actions of aqueous extract. Indian Journal of Medical Research, 48, 457-464.

Aggarwal, S., Gupta, V., \& Narayan, R. (2012). Ecological study of wild medicinal plants in a dry tropical peri-urban region of Uttar Pradesh in India. International Journal of Medicinal and Aromatic Plants, 2, 246-253. http://www. openaccessscience.com/pdf-files/vol2_2_jun2012/IJMAP_2_2_6_periurbanregion.pdf. Accessed 18 Dec 2015.

Agoyi, E. E., Assogbadjo, A. E., Gouwakinnou, G., Okou, F. A., \& Sinsin, B. (2014). Ethnobotanical Assessment of Moringa oleifera Lam. in Southern Benin (West Africa). Ethnobotany Research and Applications, 12, 551-560.

Agrawal, A., Srivastava, S., Srivastava, J. N., \& Srivasava, M. M. (2004). Evaluation of Inhibitory Effect of the Plan Phyllanthus amarus Against Dermatophytic Fungi Microsporum gypserum. Biomedical and Environmental Sciences, 17(3), 359-365. http://www.besjournal.com/freeArticles/pastlssues/2004/No3/200701/P0200701 1069974790254332200417314758.pdf. Accessed 22 Dec 2015

Ahmad, N., Hassan, M. R., Halder, H., \& Bennoor, K. S. (1999). Effect of Momordica charantia (Karolla) extracts on fasting and postprandial serum glucose levels in NIDDM patients. Bangladesh Medical Research Council Bulletin, 25(1), 11-13 (PMID:10758656).

Ajala, T. O., Igwilo, C. I., Oreagba, I. A., \& Odeku, O. A. (2011). The antiplasmodial effect of the extracts and formulated capsules of Phyllanthus amarus on Plasmodium yoelii infection in mice. Asian Pacific Journal of Tropical Medicine, 4(4), 283-287. doi:10.1016/S1995-7645(11)60087-4.

Akhtar, M. S., \& lqbal, J. (1991). Evaluation of the hypoglycaemic effect of Achyranthes aspera in normal and alloxandiabetic rabbits. Journal of Ethnopharmacology, 31(1), 49-57. doi:10.1016/0378-8741(91)90143-2.

Alagesaboopathi, C. (2011). Ethnomedicinal plants used as medicine by the Kurumba tribals in Pennagaram Region, Dharmapuri District of Tamil Nadu, India. Asian Journal of Experimental Biological Sciences, 2(1), 140-142. ISSN: 0975-5845. Accessed at http://ajebs.com/vol5/24.pdf.

Albert-Baskar, A., \& Ignacimuthu, S. (2010). Chemopreventive effect of Cynodon dactylon (L.) Pers. extract against DMHinduced colon carcinogenesis in experimental animals. Experimental and Toxicologic Pathology, 62(4), 423-431. doi:10.1016/j.etp.2009.06.003.

Al-Mamun, R., Hamid, A., Islam, M. K., \& Chowdhury, J. A. (2010). Cytotoxic and thrombolytic activity of leaves extract of Parthenium hysterophorus (Fam: Asteraceae). Bangladesh Pharmaceutical Journal, 13(2), 51-54. ISSN: 0301-4606. http://www.bps-bd.org/journal/volume13_2/10.pdf. Accessed 22 Dec 2015.

Amjad, M. S., Arshad, M., \& Qureshi, R. (2015). Ethnobotanical inventory and folk uses of indigenous plants from Pir Nasoora National Park, Azad Jammu and Kashmir. Asian Pacific Journal of Tropical Biomedicine, 5(3), 234-241. doi:10.1016/S2221-1691(15)30011-3.

Anand, et al. (2014). Phyto Chemical Investigation and Evaluation of Analgesic Activity Of Physalis Minima. World Journal of Pharmacy and Pharmaceutical Sciences, 3(10), 471-478.

Anderies, J., Janssen, M. \& Ostrom, E. (2004). A framework to analyze the robustness of social-ecological systems from an institutional perspective. Ecology and Society, 9(1)

Ananth, K. V., et al. (2010). Evaluation of wound healing potential of Bauhinia purpurea leaf extracts in rats. Indian Journal of Pharmaceutical Sciences, 72(1), 122.

Anonymous. (1989). The Wealth of India: Raw Materials Series (pp. 33-34). New Delhi: Publications and Information Directorate.

Anuradha, S. U., Vartak, V. D., \& Kumbhojkar, M. S. (1994). Ethno-medico-botanical studies in Western Maharashtra, India. Ethnobotany, 6, 25-31.

Aruna, D., Chakarvarthy, K., \& SarathBabu, K. (2013). Evaluation of Diuretic Activity of Cynodondactylon in Rats with Comparison of Hydrochlorothiazide. IJRPBS, 4(2). http://www.jijpbsonline.com/files/10-4193.pdf. Accessed 3 Dec 2015.

Attanayake, A. P., Jayatilaka, K. A., Pathirana, C., \& Mudduwa, L. K. (2013). Study of antihyperglycaemic activity of medicinal plant extracts in alloxan induced diabetic rats. Ancient Science of Life, 32(4), 193. doi:10.4103/0257-7941.131970.

Awad, M. M., Ragab, E. A., \& Atef, A. (2015). Phytochemical investigation and biological evaluation of Dichanthium annulatum (Forrsk). Journal of Scientific and Innovative Research, 4(3), 131-137. ISSN: 2320-4818

Awasthi, C. P., \& Singh, A. B. (2000). Nutritional quality evaluation of edible leaves of some promising Colocasia and Alocasia collections. Indian Journal of Agriculture Research, 34(2), 117-121 ISSN: 0367-8245.

Awobajo, F. O., Omorodion-Osagie, E., Olatunji-Bello, I. I., Adegoke, O. A., \& Adeleke, T. L. (2009). Acute oral toxicity test and phytochemistry of some west African medicinal plants. Nigerian Quarterly Journal of Hospital Medicine, 19(1), 53-58 http://dx.doi.org/10.4314/nqjhm.v19i1.50209.

Babu, D.R., Neeharika, V., Pallavi, V. and Reddy, M.B. (2009). Antidiarrheal activity of Cynodon Dactylon. pers. Pharmacognosy Magazine, 5(19), 23.

Bafna, A. R., \& Mishra, S. H. (2004). Effect of methanol extract of Achyranthes aspera Linn. on rifampicin-induced hepatotoxicity in rats. Ars Pharmaceutica, 45(4), 343-351. ISSN-e 0004-2927. 
Bagali, R. S., \& Jalalpure, S. S. (2010). Evaluation of antidiabetic and antioxidant effect of Schrebera swietenioides fruit ethenolic extract. Der Pharmacia Lettre, 2(5), 278-288.

Bagalkotkar, G., Sagineedu, S. R., Saad, M. S., \& Stanslas, J. (2006). Phytochemicals from Phyllanthus niruri Linn. and their pharmacological properties: a review. Journal of Pharmacy and Pharmacology, 58(12), 1559-1570. doi:10.1211/jpp.58.12.0001.

Baheti, J., \& Awati, S. (2013). Antiasthmatic Activity of Leptadenia reticulata (Retz) Wt \& Arn leaves. In 3rd International Conference on Applied Mathematics and Pharmaceutical Sciences (ICAMPS'2013), Singapore (pp. 335-339).

Balangcod, T. D., \& Balangcod, A. K. D. (2011). Ethnomedical knowledge of plants and healthcare practices among the Kalanguya tribe in Tinoc, Ifugao, Luzon, Philippines. Indian Journal of Traditional Knowledge, 10(2), 227-238. ISSN: 0975-1068. Accessed at http://nopr.niscair.res.in/bitstream/123456789/11497/1/IJTK\%2010\%282\%29\%20227-238.pdf

Bamidele, O., Arokoyo, D. S., Akinnuga, A. M., \& Oluwarole, A. O. (2014). Antidiabetic effect of aqueous extract of Basellaalba leaves and metformin in alloxan-induced diabetic albino rats. African Journal of Biotechnology, 13(24), 2455-2458. ISSN: 1684-5315. Accessed at http://www.academicjournals.org/app/webroot/article/ article1402926863 Bamidele\%20et\%20al.pdf.

Baquar, S. R. (1989). Medicinal and poisonous plants of Pakistan. Medicinal and Poisonous Plants of Pakistan, 201.

Barua, C. C., Talukdar, A., Begum, S. A., Buragohain, B., Roy, J. D., Borah, R. S., \& Lahkar, M. (2009). Antidepressantlike effects of the methanolic extract of Achyranthes aspera Linn. in animal models of depression. Pharmacologyonline, 2, 587-594. http://pharmacologyonline.silae.it/files/archives/2009/vol2/059.Barua.pdf. Accessed 15 Dec 2015.

Bedi, S. J. (1978). Ethnobotany of the Ratan Mahal Hills, Gujarat, India. Economic Botany, 32(3), 278-284. doi:10.1007/BF02864701. Bensky, D., Gamble, A., \& Kaptchuk, T. J. (1993). Chinese herbal medicine: materia medica. Seattle: Eastland Press.

Bhangale, J., \& Acharya, S. (2014). Antiarthritic activity of Cynodon dactylon (L.) Pers. Indian Journal of Experimental Biology, 52(2014), 215-22. Accessed at http://imsear.li.mahidol.ac.th/bitstream/123456789/150351/1/ ijeb2014v52n3p215.pdf

Bhatia, L., Bishnoi, H., Chauhan, P., Kinja, K., \& Shailesh, S. (2011). In vitro comparative antioxidant activity of ethanolic extracts of Glycosmis pentaphylla and Bauhinia variegate. Recent Research in Science and Technology, 3(7), 1-3.

Bhatt, S. K., \& Saxena, V. K. (1980). Antifungal activity of seeds extracts of Alocasia indica. Indian Drugs, 17(7), 210-211.

Bhatt, T., Jain, V., Jayathirtha, M. G., Banerjee, G., \& Mishra, S. H. (2002). In vitro regeneration of roots of Phyla nodiflora and Leptadenia reticulata, and comparison of roots from cultured and natural plants for secondary metabolites. Indian Journal of Experimental Biology, 40(12), 1382-1386 ISSN: 0975-1009 (Online).

Bhattacharya, B. (2011). In-vivo and in-vitro anticancer activity of Coccinia grandis (L.) Voigt.(Family: Cucurbitaceae) on Swiss albino mice. Journal of Pharmacy Research, 4(3), 567-569. doi:10.13140/RG.2.1.2917.9603.

Bhattacharya, M. S., Ghosh, S., Datta, S., Samanta, A., Das, G., \& Durbadal Ojha, B. (2010). Evaluation of antimicrobial potentialities of leaves extract of the plant Cassia tora Linn.(Leguminosae/Caesalpinioideae). Journal of Phytology, 2(5).

Bhattarai, N. K. (1993). Folk herbal remedies for diarrhoea and dysentery in central Nepal. Fitoterapia, 64, 243-250.

Bheemachari, J., Ashok, K., Joshi, N. H., Suresh, D. K., \& Gupta, V. R. M. (2007). Antidiarrhoeal evaluation of Ficus racemosa Linn. latex. Acta Pharmaceutica Sciencia, 49(2), 133-138.

Bindu, V., \& Jain, B. K. (2011). Allelopathic effect of Digera muricata (L.) mart onin vitroseed germination of Pennisetum typhoideum. International Journal of Plant Sciences, 6(2), 332-334. http://www.researchjournal.co.in/online/IJPS/ IJPS\%206(2)/6_A-332-334.pdf. Accessed 13 Dec 2015.

Bing, L. I. N. G., Wang, G. C., Ji, Y. A., Zhang, M. X., \& Liang, G. W. (2008). Antifeedant activity and active ingredients against Plutella xylostella from Momordica charantia leaves. Agricultural Sciences in China, 7(12), 1466-1473. doi:10. 1016/S1671-2927(08)60404-6.

Bodhanapu, S., \& Sreedhar, S. (2011). Antiulcer Activity Of Aqueous Extract Of Leptadenia Reticulata. Inventi Rapid: Ethnopharmacology. Pharmacologyonline, 2, 1190-1196.

Bolay, B., et al. (2010). In vitro evaluation of antifungal and Antibacterial activities of the plant Cocciniagrandis (L.) Voigt. (FamilyCucurbitaceae). Journal of Phytology, 2(11), 52-57.

Bose, U., Bala, V., Ghosh, T. N., Gunasekaran, K., \& Rahman, A. A. (2011). Antinociceptive, cytotoxic and antibacterial activities of Cleome viscosa leaves. Revista Brasileira de Farmacognosia, 21(1), 165-169 http://dx.doi.org/10.1590/ S0102-695X2011005000023.

Bourinbaiar, A. S., \& Leehuang, S. (1995). Potentiation of anti-HIV activity of anti-inflammatory drugs, dexamethasone and indomethacin, by MAP30, the antiviral agent from bitter melon. Biochemical and Biophysical Research Communications, 208(2), 779-785. doi:10.1006/bbrc.1995.1405.

Brito, F. A., Lima, L. A., Ramos, M. F. S., Nakamura, M. J., Cavalher-Machado, S. C., Siani, A. C., et al. (2007). Pharmacological study of anti-allergic activity of Syzygiumcumini (L.)Skeels. Brazilian Journal of Medical and Biological Research, 40(1), 105-115 ISSN: 0100-879X. Accessed at http://www.scielo.br/pdf/bjmbr/v40n1/6085.pdf.

Burkill, I. H. (1966). A dictionary of the economic products of the Malay Peninsula. (2nd edition).

Chakraborty, A., Brantner, A., Mukainaka, T., Nobukuni, Y., Kuchide, M., Konoshima, T., et al. (2002). Cancer chemopreventive activity of Achyranthes aspera leaves on Epstein-Barr virus activation and two-stage mouse skin carcinogenesis. Cancer Letters, 177(1), 1-5. doi:10.1016/50304-3835(01)00766-2.

Chalmers, D. (2013). Social innovation: An exploration of the barriers faced by innovating organizations in the social economy. Local Economy, 28(1), 17-34.

Chandra, D. (2001). Analgesic effect of aqueous and alcoholic extracts of Madhuka Longifolia (Koeing). Indian Journal of Pharmacology, 33(2), 108-111. Accessed at http://medind.nic.in/ibi/t01/i2/ibit01i2p108.pdf.

Chang Chang, H. M., \& But, P. P. (1986). Pharmacology and applications of Chinese material medical Nol. 2). Singapore: World Scientific.

Chang, M. (1992). Anticancer Medicinal Herbs. Changsha: Human Science and Technology Publishing House.

Channabasavaraj, K. P., Badami, S., \& Bhojraj, S. (2008). Hepatoprotective and antioxidant activity of methanol extract of Ficus glomerata. Journal of Natural Medicines, 62(3), 379-383. doi:10.1007/s11418-008-0245-0.

Chaudhari, S. K., Arshad, M., Ahmed, E., Mustafa, G., Fatima, S., Akhter, S., \& Amjad, M. S. (2013). Ethnobotanical evaluation of grasses from Thal Desert. Pakistan, 248-255. 
Chaudhari, Y., Mody, H. R., \& Acharya, V. B. (2011). Antibacterial activity of Cynodondactylon on different bacterial pathogens isolated from clinical samples. International Journal of Pharmaceutical Studies and Research, 1, 16-20. ISSN: 0975-1491 Accessed at file://C:/Users/IMA/Downloads/PRELIMINARY_PHYTOCHEMICAL_STUDY_AND_ANTI.pdf.

Chenniappan, K., \& Kadarkarai, M. (2010). In vitro antimalarial activity of traditionally used Western Ghats plants from India and their interactions with chloroquine against chloroquine-resistant Plasmodium falciparum. Parasitology Research, 107(6), 1351-1364. doi:10.1007/s00436-010-2005-9.

Chetty, K. M., Chetty, M. L., Sudhakar, A., \& Ramesh, C. (1998). Ethno-medico botany of some aquatic angiospermae in Chittoor district of Andhra Pradesh, India. Fitoterapia, 69(1), 7-12.

Chidume, F. C., Kwanashie, H. O., Adekeye, J. O., Wambebe, C., \& Gamaniel, K. S. (2002). Antinociceptive and smooth muscle contracting activities of the methanolic extract of Cassia tora leaf. Journal of Ethnopharmacology, 81(2), 205-209. doi:10.1016/50378-8741(02)00079-X.

Chopda, M. Z., \& Mahajan, R. T. (2009). Wound healing plants of Jalgaon district of Maharashtra state, India. Ethnobotanical Leaflets, 1, 1. http:/opensiuc.lib.siu.edu/cgi/viewcontent.cgi?article=1318\&context=ebl. Accessed 5 Dec 2015.

Chopra, R. N., Nayar, S. L., \& Chopra, I. C. (2002). Glossary of Indian medicinal plants, National institute of science communication and information resources. New Delhi: CSIR (Six Reprient) - 42, 214

Choudhury, M. D., Bawari, M., \& Singha, L. S. (2010). Some antipyretic ethno-medicinal plants of manipuri community of Barak valley, Assam, India. Ethnobotanical Leaflets, 4(1), 21-28 http://opensiuc.lib.siu.edu/ebl/vol2010/iss1/4.

Cipriani, T. R., Mellinger, C. G., de Souza, L. M., Baggio, C. H., Freitas, C. S., Marques, M. C., et al. (2008). Acidic heteroxylans from medicinal plants and their anti-ulcer activity. Carbohydrate Polymers, 74(2), 274-278. doi:10.1016/j.carbpol.2008.02.012.

Colagar, A. H., \& Souraki, O. A. (2011). Review of Pumpkin Anticancer Effects. Quran and Medicine, 1(4), 77-88. doi:10.5812/quranmed.8923.

Dandiya, P. C., \& Chopra, Y. M. (1970). CNS-active drugs from plants indigenous to India. Indian Journal of Pharmacology, 2(3), 67. https://books.google.co.in/books?id=3clmAgAAQBAJ\&pg=PA158\&lpg=PA158\&dq= Leptadenia+reticulata+gangrene\&source=bl\&ots=SHEpf3CIIT\&sig=r8RJoAEatdxytF7WHj6_z8H4G5w\&hl=en\&sa= X\&ved=0ahUKEwjCo_if9t3KAhVPbY4KHWZqA2KQ6AEIMTAD\#v=onepage\&q= Leptadenia\%20reticulata\%20gangrene\&f=false. Accessed 26 Dec 2015.

Dangol, D. R. (2008). Traditional uses of plants of commonland habitats in Western Chitwan, Nepal. Journal of the Institute of Agriculture and Animal Science, 29, 71. http://www.ncbi.nlm.nih.gov/pmc/articles/PMC3432267/. Accessed 11 Dec 2015

Datir, S. B., Ganjare, A. B., Nirmal, S. A., Bhawar, S. B., Bharati, D. K., \& Patil, M. J. (2009). Evaluation of antiallergic activity of the various extracts of the aerial part of achyranthes aspera var. Porphyristachya (wall. Ex moq.) Hook. F.921-925. http://pharmacologyonline.silae.it/files/newsletter/2009/vol3/92.Datir.pdf. Accessed 11 Dec 2015.

Defourny, J., \& Nyssens, M. (2008). Social enterprise in Europe: recent trends and developments. Social Enterprise Journal, 4(3), 202-228.

Deoda Ramesh S et al. (2012). Antilithiatic Activity of Leaves, Bulb and Stem Of NympheaOdorata and Dolichos Lablab Beans. Research Journal of Pharmaceutical, Biological and Chemical Sciences, 3(1), 814-819.

Devaraj, V. C., Asad, M., \& Prasad, S. (2007). Effect of Leaves and Fruits of Moringa oleifera. on Gastric and Duodenal Ulcers. Pharmaceutical Biology, 45(4), 332-338. doi:10.1080/13880200701212924. http://www.encognitive.com/files/ Effect\%20of\%20Leaves\%20and\%20Fruits\%20of\%20Moringa\%20oleifera\%20on\%20Gastric\%20and\%20Duodenal\% 20Ulcers.pdf. Accessed 9 Dec 2015

Devarkar, V. D., Marathe, V. R. \& Chavan, D. P. (2011). Dietary and medicinal significance of wild vegetables from Osmanabad region, Maharashtra (India). Life Sciences Leaflets, 11, 317-332. http://api.ning.com/files/42ptSX3mtU2qdOLIfU6EtNEr4Buh8bVehT5OX-INesaYEXIwbvBJWX7zunMinUNOeQBNdsgfpOFR9o**1tf7q-XxEz7ARjH/317. DIETARYANDMEDICINALSIGNIFICANCEOFWILDVEGETABLESFROMOSMANABADREGIONMAHARASHTRAINDIABYV.D. DEVARKARV.R.MARATHE1ANDD.P.CHAVAN2.pdf.pdf. Accessed 28 Dec 2015.

Devi Yumnam Ambrabati, Vrushabendra Swamy BM, Vishwanath Swamy KM, Ramu Ravi Rala. (2012). Antidiabetic activity of Echinochloa crusgalli (L.)P.Beauv grains extract in alloxan induced diabetic rats. RJPBCS. 3(4) pp. 1257-1275. http://www.rjpbcs.com/pdf/2012_3(4)/[140].pdf. Accessed 14 Dec 2015.

Devi, S. G., Archanah, A., Abiramasundari, P., Priya, V., Uma, K., \& Abirami, T. (2009). Comparative evaluation of the antioxidant status and in vitro free radical scavenging activities of leaves and roots of Achyranthes aspera. Indian Journal of Nutrition and Dietetics, 46(12), 485-490 ISSN: 0022-3174.

Dey, A., Singh, G., \& Gupta, A. (2015). Women and Climate Stress: Role Reversal from Beneficiaries to Expert Participants, world development, (article in press).

Dey, A., Singh, G., \& Gupta A.K. (2017). Open Innovation at different levels for Higher Climate Risk Resilience Science, Technology and Society, SAGE, forthcoming (ISSN: 0971-7218).

Dharamveer, Q., et al. (2009). Cns Depressat Activity of Ethaolic Extract Of Physalis. Milima Li. Fruit. Pharmacologyonline, 2, 707-710. http://pharmacologyonline.silae.it/files/newsletter/2009/vol2/71.Gupta.pdf. Accessed 14 Dec 2015.

Duke, J. A. (2002). Handbook of medicinal herbs (pp. 315-316). Boca Raton: CRC press ISBN: 1420040464, 9781420040463.

Duke, J. A., \& Ayensu, E. S. (1985). Medicinal plants of China (Vol. 2). Algonac: Reference Publications. doi:10.1002/fedr. 19870980707 ISBN 0-917266-20-4.

Duke, J. A., \& Wain, K. K. (1981). Medicinal plants of the world. Computer index with more than 85000 entries. Medicinal plants of the world: Computer index with more than 85,000 entries.

Duraisami, R., Mohite, V. A., \& Kasbe, A. J. (2010). Anti stress, adaptogenic activity of standardized dried fruit extract of aegle marmelos against diverse stressors. Asian Journal of Pharmaceutical and Clinical Research, 3(4), 1-3. http://www.ajpcr.com/Nol3lssue4/5.pdf. Accessed 8 Dec 2015.

EL Hawary, S. S., Wassel, G. M., \& El Menshawi, B. S. (2012). Antitumor and antioxidant activity of FicuselasticaRoxb and FicusicusbenghalensisLinn.familyMoraceae. World Applied Sciences Journal, 19(11), 1532-1539. Accessed at http:// idosi.org/wasj/wasj19(11)12/1.pdf.

El Molla, S. G., Motaal, A. A., El Hefnawy, H., \& El Fishawy, A. (2015). Cytotoxic activity of phenolic constituents from Echinochloa crus-galli against four human cancer cell lines. Revista Brasileira de Farmacognosia. doi:10.1016/j.bjp. 2015.07.026. 
Eshwarappa, R. S. B., Iyer, R. S., Subbaramaiah, S. R., Richard, S. A., \& Dhananjaya, B. L. (2014). Antioxidant activity of Syzygium cumini leaf gall extracts. Biolmpacts: BI, 4(2), 101. doi:10.5681/bi.2014.018.

Ezeonwu, V. U. (2011). Antifertility Activity of Aqueous Extract of Phyllanthus niruri in Male Albino Rats. The Internet Journal of Laboratory Medicine, 4(2). http://www.studentpulse.com/articles/577/antifertility-effects-ofaqueous-extractof-phyllanthus-niruri-in-male-albino-rats. Accessed 14 Dec 2015.

Faizi, S., Siddiqui, B. S., Saleem, R., Siddiqui, S., Aftab, K., \& Gilani, A. U. H. (1994). Isolation and structure elucidation of new nitrile and mustard oil glycosides from Moringa oleifera and their effect on blood pressure. Journal of Natural Products, 57(9), 1256-1261. doi:10.1021/np50111a011.

Fazal, H. I. N. A., Ahmad, N., Ullah, I., Inayat, H., Khan, L., \& Abbasi, B. H. (2011). Antibacterial potential in Parthenium hysterophorus, Stevia rebaudiana and Ginkgo biloba. Pakistan Journal of Botany, 43(2), 1307-1313. http://www. pakbs.org/pjbot/PDFs/43(2)/PJB43(2)1307.pdf. Accessed 26 Dec 2015.

Friedman, M. (2003). Chemistry, biochemistry, and safety of acrylamide. A review. Journal of Agricultural and Food Chemistry, 51(16), 4504-4526. doi:10.1021/ff030204. http://xexxus.net/PDFfiles/AcrylamideJAgricFoodChem2003..pdf. Accessed 24 Dec 2015.

Gaikwad, R. D., Ahmed, M. L., Khalid, M. S., \& Swamy, P. (2009). Anti-inflammatory activity of Madhuca longifolia seed saponin mixture. Pharmaceutical Biology, 47(7), 592-597. doi:10.1080/13880200902902513.

Ganesan, A., Natesan, S., Vellayutham, R., Manickam, K., \& Ramasamy, N. (2008). Anxiolytic, antidepressant and antiinflammatory activity of methanol extract of leaves of Momordica charantia Linn (Cucurbitaceae). Iranian Journal of Pharmacology and Therapeutics, 7(1), 43-47. Accessed at http://www.sid.ir/EN/NEWSSID/J_pdf/101020080108.pdf.

Gangrade, N. K., Sheorey, R. V., Rawal, H., \& Chouhan, S. (2012). Investigation of wound healing activity of Malvastrum tricuspidatum syn Malvastrum coromandelianum on experimental animals. International Journal of Pharmacy \& Life Sciences, 3(12). http://www.ijddhrjournal.com/issues/2012//V\%20issue/8.pdf. Accessed 23 Dec 2015.

Garg, V. K., \& Paliwal, S. K. (2011). Anti-inflammatory activity of aqueous extract of Cynodondactylon. International Journal of Pharmacology, 7, 370-375. doi:10.3923/ijp.2011.370.375.

Gaur, R. D. (1999). Flora of the District Garhwal, North West Himalaya. (With ethnobotanical notes) (p. 811). Srinagar Garhwal: TransMedia.

Geels, F. W. (2004). From sectoral systems of innovation to socio-technical systems: Insights about dynamics and change from sociology and institutional theory. Research Policy, 33(6), 897-920.

Gheisari, H. R., Amiri, F., \& Zolghadri, Y. (2011). International Journal of Current Pharmaceutical Research, 3, 85-88.

Ghildiyal, J. C., Juyal, P., \& Sadana, G. (2014). Indigenous uses of plants in different women ailments in Garhwal region. Indian Journal of Pharmaceutical and Biological Research, 2(1), 39. http://ijpbr.in/wp-content/uploads/2014/03/6Indigenous-uses-of-plants-in-different-women-ailments-in-Garhwal-region.pdf. Accessed 3 Dec 2015.

Ghosh, M. N. (1984). Fundamentals of experimental pharmacology (2nd ed.). Calcutta: Scientific book agency ISBN: 81902965-0-7.

Ghosh, R., Dhande, I., Kakade, V. M., Vohra, R. R., Kadam, V. J., \& Mehra. (2009). Antihyperglycemic activity of Madhucalongifolia in alloxan -induced diabetic rats. The Internet Journal of Pharmacology, 6(2), 1-12.

Gibson-Graham, J. K., \& Roelvink, G. (2013). Social innovation for community economies: how, The International Handbook on Social Innovation: Collective Action, Social Learning and Transdisciplinary Research (p. 453).

Giordano, B., Thrash, W., Hollenbaugh, L., Dube, W. P., Hodges, C., Swain, A., et al. (1989). Performance of seven blood glucose testing systems at high altitude. The Diabetes Educator, 15(5), 444-448. doi:10.1177/014572178901500515.

Goyal, B. R., Mahajan, S. G., Mali, R. G., Goyal, R. K., \& Mehta, A. A. (2007). Beneficial effect of Achyranthes apsera Linn. in toluene-di-isocyanate induced occupational asthma in rats. Glo J Pharma, 1(1), 6-12. http://idosi.org/gjp/1(1)07/2. pdf. Accessed 12 Dec 2015.

Grieve, M., \& Leyel, C. F. (1992). A Modern Herbal (p. 770). London: Tiger Books International.

Guha, R. (2006). How much should a person consume?: Environmentalism in India and the United States. Berkeley: Univ of California Press.

Gupta, A. K. (2006). From sink to source: The Honey Bee Network documents indigenous knowledge and innovations in India. Innovations, 1(3), 49-66.

Gupta, A. K., Dey, A. R., Shinde, C., Mahanta, H., Patel, C., Patel, R., et al. (2016). Theory of open inclusive innovation for reciprocal, responsive and respectful outcomes: coping creatively with climatic and institutional risks. Journal of Open Innovation: Technology, Market, and Complexity, 2(1), 16. https:/jopeninnovation.springeropen.com/articles/10. 1186/s40852-016-0038-8.

Gupta, A. K., Gowda, K. P., Umashankar, R. N., Nandeesh, R., \& Sreedhar, S. (2010). In-vitro Antioxidant Activity of Aqueous Extract of Physalis minima Linn. Research Journal of Pharmacology and Pharmacodynamics, 2(5), 332-334 ISSN: 0975-4407.

Gupta, A. K., Sinha, R., Koradia, D., Patel, R., Parmar, M., Rohit, P., et al. (2003). Mobilizing grassroots' technological innovations and traditional knowledge, values and institutions: articulating social and ethical capital. Futures, 35(9), 975-987.

Gupta, A., Kothari, B., \& Patel, K. (2000). Networking knowledge-rich, economically poor people, Information and communication technology in rural development: Case studies from India (pp. 84-97).

Gupta, A. K. (2012). How to protect the inventions of the poor. http://www.scidev.net/global/knowledge-economy/ opinion/how-to-protect-the-inventions-of-the-poor.html. Accessed 29 May 2017.

Gupta, A. K. (2013). Tapping the entrepreneurial potential of grassroots innovation. Stanford Social Innovation Review, $11(3), 18-20$.

Gupta, S., Garg, V. K., Sharma, P. K., \& Singh, A. (2011). Analgesic activity of aqueous extract of Musa paradisiaca. Der Pharmacia Sinica, 2(4), 74-77.

Hakim, R. (1964). The Use Of Malkanguni With Other Indigenous Drugs In The Treatment Of Depression. Indian Journal of Psychiatry, 6(3), 142.

Haryanti, S., Junedi, S., \& Meiyanto, E. (2013). Ethanolic extract of Hedyotis corymbosa L. increases cytotoxic activity of doxorubicin on MCF-7 breast cancer cell. Indonesian. Journal of Biotechnology, 14(1). http://ijbiotech.ugm.ac.id/ojs/ index.php/biotech/article/view/183. Accessed 14 Dec 2015. 
Hasan, M. M., Annay, M. E. A., Sintaha, M., Khaleque, H. N., Noor, F. A., Nahar, A., \& Rahmatullah, M. (2010). A survey of medicinal plant usage by folk medicinal practitioners in seven villages of Ishwardi Upazilla, Pabna district, Bangladesh. American-Eurasian Journal of Sustainable Agriculture, 4(3), 334-340 ISSN: 1995-0748.

Hasan, S. M., Hossain, M. M., Faruque, A., Mazumder, M. E. H., Rana, M. S., Akter, R., \& Alam, M. A. (2008a). Comparison of antioxidant potential of different fractions of Commelina benghalensis Linn. Bangladesh J. Life Sci, 20(2), 9-16.

Hasan, S. M., Hossain, M. M., Faruque, A., Mazumder, M. E. H., Rana, M. S., Akter, R., \& Alam, M. A. (2008b). Comparison of antioxidant potential of different fractions of Commelina benghalensis Linn. Bangladesh J. Life Sci, 20(2), 9-16.

Herrera, M.E.B. (2015). Creating competitive advantage by institutionalizing corporate social innovation. Journal of Business Research, 68(7), 1468-1474.

Honey Bee Network. (1990-2017). www.honeybee.org.

Hossain, F., et al. (2014). Analgesic and Anti-Infammatory Activity of Commelina benghalensis Linn. Turk J Pharm Sci, 11(1), 25-32. http://eski.teb.org.tr/images/upld2/ecza_akademi/dergi/1112014\%20(1)\%2025-32.pdf. Accessed 22 Dec 2015.

Hossain, H., Al-Mansur, A., Akter, S., Sara, U., Ahmed, M. R., \& Jahangir, A. A. (2014). Evaluation of anti-inflammatory activity and total tannin content from the leaves of Bacopa monnieri (Linn.) International Journal of Pharmaceutical Sciences and Research, 5(4), 1246. http://crawl.prod.proquest.com.s3.amazonaws.com/fpcache/ 0e45d1341ef90d033398977d4bbcbff6.pdf?AWSAccessKeyld=AKIAJF7V7KNV2KKY2NUQ\&Expires= 1453887786\&Signature=ZVRWTX1oMtpooJe5WQkl6utBhXQ\%3D. Accessed 5 Dec 2015.

Hudson, L., \& Frank, H. C. (1991). Practical immunology (3rd ed.). London: Black well publications. Oxford university press.

Hukkeri, V. I., Nagathan, C. V., Karadi, R. V., \& Patil, B. S. (2006). Antipyretic and wound healing activities of moringaoleifera lam in rats. Indian Journal of Pharmaceutical Sciences, 68(1), 124-126. doi:10.4103/0250-474X.22985.

Hussain, A. (2008). Evaluation of anthelmintic activity of some ethnobotanicals (Doctoral dissertation), department of parasitology faculty of veterinary science, university of agriculture, Faisalabad, Pakistan. 87. http://prr.hec.gov.pk/ thesis/110s.pdf. Accessed 14 Dec 2015.

Iranloye, B. O., Owoyele, V. B., Kelani, O. R., \& Olaleye, S. B. (2011). Analgesic activity of aqueous leaf extract of Phyllanthus amarus. African Journal of Medicine and Medical Sciences, 40(1), 47-50 (PMID:21834261).

Islam, M. K., Saha, S., Mahmud, I., Mohamad, K., Awang, K., Uddin, S. J., et al. (2014). An ethnobotanical study of medicinal plants used by tribal and native people of Madhupur forest area, Bangladesh. Journal of Ethnopharmacology, 151(2), 921-930. doi:10.1016/j.jep.2013.11.056.

Islam, M., Ali, E., Saeed, M. A., Jamshaid, M., \& Khan, M. T. J. (2007, 2010). Antimicrobial and Irritant activities of the extracts of Malva Parviflora L., Malvastrum Coromandelianum L. and Amaranthus viridis L.-A Preliminary Investigation. Pakistan Journal of Pharmacy, 20-23. http://pu.edu.pk/images/journal/PJP/pdf-files/P1_TJKhan.pdf. Accessed 14 Dec 2015.

Iwu, M. M. (1993). Handbook of African Medicinal Plants (pp. 111-113). Boca Raton: CRC Press ISBN: 1466571977, 9781466571976

Jadhav, V. D., Mahadkar, S. D., \& Valvi, S. R. (2012). Documentation and ethnobotanical survey of wild edible plants from Kolhapur district. Recent Research in Science and Technology, 3(12). ISSN: 2230-8407. Accessed at http://www. irjponline.com/admin/php/uploads/2386_pdf.pdf.

Jagatha, G., \& Senthilkumar, N. (2011a). Evalution of anti-diabetic activity of methanol extract of digera muricata (I) mart in alloxan induced diabetic rats. International Journal of Pharmaceutical Sciences and Research, 2(6), 748-752. http://citeseerx.ist.psu.edu/viewdoc/download?doi=10.1.1.278.5468\&rep=rep1\&type=pdf. Accessed 27 Dec 2015.

Jagatha, G., \& Senthilkumar, N. (2011 b). Evalution of anti-diabetic activity of methanol extract of digera muricata (I) mart in alloxan induced diabetic rats. International Journal of Pharmaceutical Sciences and Research, 2(6), 748-752. http:// citeseerx.ist.psu.edu/viewdoc/download?doi=10.1.1.278.5468\&rep=rep1\&type=pdf. Accessed 23 Dec 2015.

Jain, S. K. (1991a). Dictionary of Indian folk medicine and ethnobotany (p. 311). New Delhi: Deep publications.

Jain, S., \& Patil, U. K. (2010). Phytochemical and Pharmacological Profile of Cassia tora Linn-An overview. Indian Journal of Natural Products and Resources, 1(4), 430-437.

Jain, S. K. (1991b). Dictionary of Indian folk medicine and ethnobotany. New Delhi: Deep Publications.

Janbaz, K. H., \& Saqib, F. (2015). Pharmacological evaluation of Dactyloctenium aegyptium: An indigenous plant used to manage gastrointestinal ailments. Bangladesh Journal of Pharmacology, 10(2), 295-302. doi:10.3329/bjp.v10i2.21811 http://www.banglajol.info/index.php/BJP/article/view/21811/15767. Accessed 25 Dec 2015.

Jarald, E. E., Joshi, S. B., \& Jain, D. C. (2008). Antidiabetic activity of aqueous extract and non polysaccharide fraction of CynodondactylonPers. Indian Journal of Experimental Biology, 46(9), 660. ISSN: 0975-1009. Accessed at http://nopr. niscair.res.in/bitstream/123456789/4578/1/IJEB\%2046\%289\%29\%20660-667.pdf.

Jayakumar, T., Sridhar, M. P., Bharathprasad, T. R., llayaraja, M., Govindasamy, S., \& Balasubramanian, M. P. (2009). Experimental studies of Achyranthes aspera $(L)$ preventing nephrotoxicity induced by lead in albino rats. Journal of Health Science, 55(5), 701-708. http://doi.org/10.1248/jhs.55.701.

Jayasooriya, A. P., Sakono, M., Yukizaki, C., Kawano, M., Yamamoto, K., \& Fukuda, N. (2000). Effects of Momordica charantia powder on serum glucose levels and various lipid parameters in rats fed with cholesterol-free and cholesterol-enriched diets. Journal of Ethnopharmacology, 72(1), 331-336. doi:10.1016/S0378-8741(00)00259-2.

Jebastella, J., \& Reginald Appavoo, M. (2015). Screening Of Antibacterial Activity In Medicinal Grass (Dactyloctenium Aegyptium) Using Two Extract. International Journal of Recent Scientific Research., 6(7), 5046-5048.

Jeyaprakash, K., Ayyanar, M., Geetha, K. N., \& Sekar, T. (2011). Traditional uses of medicinal plants among the tribal people in Theni District (Western Ghats), Southern India. Asian Pacific Journal of Tropical Biomedicine, 1(1), S20-S25. doi:10.1016/S2221-1691(11)60115-9. Accessed at http://ugcdskpdf.unipune.ernet.in/Journal/ uploads/BL/BL080183-A-3.pdf.

Joshi, P. V., Patil, R. H., \& Maheshwari, V. L. (2009). In vitro anti diarrhoeal activity and toxicity profile of Aegle marmelos Correa ex. Roxb. dried fruit pulp. Natural Product Radiance, 8(5), 498-502.

Kala, C. P., Dhyani, P. P., \& Sajwan, B. S. (2006). Developing the medicinal plants sector in northern India: challenges and opportunities. Journal of Ethnobiology and Ethnomedicine, 2, article 32. doi:10.1186/1746-4269-2-32. http:// 
download.springer.com/static/pdf/183/art\%253A10.1186\%252F1746-4269-2-32.pdf?originUrl= http\%3A\%2F\%2Fethnobiomed.biomedcentral.com\%2Farticle\%2F10.1186\%2F1746-4269-2-32\&token2=exp= 1454078877 acl=\%2Fstatic\%2Fpdf\%2F183\%2Fart\%25253A10.1186\%25252F1746-4269-2-32.pdf* $\sim \mathrm{hmac}=$ 584adada58ca4adae2d77a7768a4f376a5fce6b1365eca67dbe2e643c46e6677. Accessed 19 Dec 2015.

Kamalakkannan, N., \& Prince, P. S. M. (2003). Hypoglycaemic effect of water extracts of Aegle marmelos fruits in streptozotocin diabetic rats. Journal of Ethnopharmacology, 87(2), 207-210.

Kaou, A. M., Mahiou-Leddet, V., Hutter, S., Ainnouddine, S., Hassani, S., Yahaya, I., et al. (2008). Antimalarial activity of crude extracts from nine African medicinal plants. Journal of Ethnopharmacology, 116(1), 74-83. doi:10.1016/j.jep.2007.11.001

Khan, R. U., Wazir, S. M., Subhan, M., Ullah, S., Ullah, H., Farooq, A., Jaffar, F., Shazia, I. A. S., \& Kamal, M. (2012). Weed flora of sugarcane in district Bannu, Khyber Pakhtunkhawa, Pakistan. Pakistan Journal of Weed Science Research, 18.4, 541-552. Accessed at https://www.researchgate.net/publication/276352780_WEED_FLORA_OF_SUGARCANE_IN_ DISTRICT_BANNU_KHYBER_PAKHTUNKHAWA_PAKISTAN.

Khan, A. V., \& Khan, A. A. (2008). Ethnomedicinal uses of Eclipta prostrata Linn. Indian Journal of Traditional Knowledge, 316 http://nopr.niscair.res.in/bitstream/123456789/1593/1/IJK\%207(2)\%20316-320.pdf. Accessed 23 Dec 2015.

Khan, J., Khan, R., \& Qureshi, R. A. (2013a). Ethnobotanical study of commonly used weeds of District Bannu, Khyber Pakhtunkhwa (Pakistan). J Med Plants Stud, 1(6). Accessed at http:/wwww.ncbi.nlm.nih.gov/pmc/articles/ PMC4224714/pdf/AJP-4-364.pdf.

Khan, J., Khan, R., \& Qureshi, R. A. (2013b). Ethnobotanical study of commonly used weeds of District Bannu, Khyber Pakhtunkhwa (Pakistan). J Med Plants Stud, 1(6). http://www.plantsjournal.com/vol11ssue1/lssue_march_2013/1.pdf. Accessed 8 Dec 2015

Khond, M., Bhosale, J. D., Arif, T., Mandal, T. K., Padhi, M. M., \& Dabur, R. (2009). Screening of some selected medicinal plants extracts for in-vitro antimicrobial activity. Middle-East Journal of Scientific Research, 4(4), 271-278.

Khonsung, P., Nantsupawat, S., Jesadanont, S. N., Chantharateptawan, V., \& Panthong, A. (2006). Anti-inflammatory and analgesic activities of water extract of Malvastrum coromandelianum (L.) Garcke. Thai J Pharmacol, 28, 8-15. http:// www.thaipharmacol.org/journal/2006/v28n3p8-15.pdf. Accessed 6 Dec 2015.

Kilani, S., Ammar, R. B., Bouhlel, I., Abdelwahed, A., Hayder, N., Mahmoud, A., et al. (2005). Investigation of extracts from (Tunisian) Cyperus rotundus as antimutagens and radical scavengers. Environmental Toxicology and Pharmacology, 20(3), 478-484. doi:10.1016/j.etap.2005.05.012

Kim, D. I., Lee, S. H., Choi, J. H., Lillehoj, H. S., Yu, M. H., \& Lee, G. S. (2008). The butanol fraction of Eclipta prostrata (Linn) effectively reduces serum lipid levels and improves antioxidant activities in CD rats. Nutrition Research, 28(8), 550-554. doi:10.1016/..nutres.2008.05.003.

Kirtikar, K. R., \& Basu, B. D. (1975). Indian medicinal plants (Vol. 1, 2nd ed.pp. 183-185). New Delhi: Periodical Experts.

Kirtikar, K. R., \& Basu, B. D. (1994). Indian Medicinal Plants (Vol. 2, p. 1263). Dehradun: Bishen Singh Mahendrapal Singh.

Kirtikar, K. R., \& Basu, B. D. (1999). Indian medicinal plants (pp. 1052-1054). Dehradun: International Book Distributor.

Kiruthiga, K., Saranya, J., Eganathan, P., Sujanapal, P., \& Parida, A. (2011). Chemical composition, antimicrobial, antioxidant and anticancer activity of leaves of Syzygium benthamianum (Wight ex Duthie) Gamble. Journal of Biologically Active Products from Nature, 1(4), 273-278. doi:10.1080/22311866.2011.10719094.

Kowsalya, R., Kaliaperumal, J., Vaishnavi, M., \& Namasivayam, E. (2015). Anticancer activity of Cynodon dactylon L. root extract against diethyl nitrosamine induced hepatic carcinoma. South Asian Journal of Cancer, 4(2), 83.

KRishnaveni, M. (2014). Antioxidant potential of Bauhinia purpurea (L) leaf. International Journal of Pharmacy and Pharmaceutical Sciences, 6(7). ISSN: 0975-1491. http://www.innovareacademics.in/journals/index.php/ijpps/article/ viewFile/1760/9892. Accessed 22 Dec 2015.

Krushna, G., Kareem, M. A., \& Devi, K. L. (2009). Antidyslipidaemic effect of Aegle marmelos Linn. fruit on Isoproterenol induced myocardial injury in rats. International Journal of Pharmacology, 6, 1-5.

Kumar, P., Arora, S., \& Yadav, Y. C. (2012). Anti-Inflammatory Activity Of Coumarin And Steroidal Fractions From Leaves Of Moringa Oleifera. International Journal of Drug Discovery and Medical Research, 1(1), 20-25. https://ijddmr.files. wordpress.com/2012/04/prashant_paper_antiinflammatory5.pdf. Accessed 10 Dec 2015.

Kumar PKumar, P. (2010). INDIAN SPINACH, Basellaalba (PUI) succulent, branched, smooth, twining herbaceous vine. Best Nutrition ISSN 2141-2502 @2013. Accessed at http://www.academicjournals.org/article/article1381400671_ Kumar\%20et\%20al.pdf.

Kumar, K. S., \& Bhowmik, D. (2010). Traditional medicinal uses and therapeutic benefits of Momordica charantia Linn. International Journal of Pharmaceutical Sciences Review and Research, 4(3), 23-28. http:// globalresearchonline.net/journalcontents/volume4issue3/Article\%20004.pdf. Accessed 8 Dec 2015.

xKumar, KP Sampath, et al. Traditional and medicinal uses of banana. Journal of Pharmacognosy and Phytochemistry, 1. 3(2012), 2278-4136. http://www.phytojournal.com/vol11ssue3/lssue_sept_2012/9.1.pdf. Accessed 4 Dec 2015.

Kumar, S., Chashoo, G., Saxena, A. K., \& Pandey, A. K. (2013). Parthenium hysterophorus: a probable source of anticancer, antioxidant and anti-HIV agents. BioMed Research International http://dx.doi.org/10.1155/2013/810734.

Kumawat, N. S., Chaudhari, S. P., Wani, N. S., Deshmukh, T. A., \& Patil, V. R. (2010). Antidiabetic activity of ethanol extract of Colocasia esculenta leaves in alloxan induced diabetic rats. Int J Pharm Tech Res, 2, 1246-1249. http://sphinxsai. com/s_v2 n2/PT_V.2No.2/phamtech_vol2no.2_pdf/PT=42\%20(1246-1249).pdf. Accessed 3 Dec 2015.

Kundu, M., Mazumder, R., \& Kushwaha, M. D. (2012). Evaluation of hepatoprotective activity of ethanol extract of Coccinia grandis (L.) Voigt. leaves on experimental rats by acute and chronic models. Oriental Pharmacy and Experimental Medicine, 12(2), 93-97. doi:10.1007/s13596-012-0057-3.

Leatherdale, B. A., Panesar, R. K., Singh, G., Atkins, T. W., Bailey, C. J., \& Bignell, A. H. (1981). Improvement in glucose tolerance due to Momordica charantia (karela). BMJ, 282(6279), 1823-1824 doi: http://dx.doi.org/10.1136/bmj.282.6279. 1823. http://www.ncbi.nlm.nih.gov/pmc/articles/PMC1506397/pdf/bmjcred00661-0011.pdf. Accessed 17 Dec 2015.

Lee, S. W., Wee, W., Yong, J. F. S., \& Syamsumir, D. F. (2011). Antimicrobial, antioxidant, anticancer property and chemical composition of different parts (corm, stem and leave) of Colocasia esculenta extract. Ann Univ Mariae Curie-Sklodowska Pharm, 24(3), 9-16. 
Lee, S. H., Jaganath, I. B., Wang, S. M., \& Sekaran, S. D. (2011). Antimetastatic effects of Phyllanthus on human lung (A549) and breast (MCF-7) cancer cell lines. PLoS ONE, 6, e20994. doi:10.1371/journal.pone.0020994.

Leelaprakash, G., Rose, J. C., Gowtham, B. M., Javvaji, P. K., \& Prasad, S. A. (2011). In vitro antimicrobial and antioxidant activity of Momordica charantia leaves. Pharmacophore, 2(4), 244-252. https://www. researchgate.net/profile/G_LEELAPRAKASH/publication/215806094_Invitro_antimicrobial_and_antioxidant_ activity_of_Momordica_charantia_leaves/links/04325252bbcfedaeb9857001.pdf. Accessed 22 Dec 2015.

Li, R. W., Leach, D. N., Myers, S. P., Lin, G. D., Leach, G. J., \& Waterman, P. G. (2004). A new anti-inflammatory glucoside from Ficus racemosa L. Planta Medica, 70(5), 421-426. doi:10.1055/s-2004-818969.

Lin, H. M., Tseng, H. C., Wang, C. J., Lin, J. J., Lo, C. W., \& Chou, F. P. (2008). Hepatoprotective effects of Solanum nigrum Linn extract against CCl 4-iduced oxidative damage in rats. Chemico-Biological Interactions, 171(3), 283-293. doi:10.1016/j.cbi.2007.08.008.

Lopez, C. M., Nitisinprasert, S., Wanchaitanawong, P., \& Poovarodom, N. (2003). Antimicrobial activity of medicinal plant extract against food borne spoilage and pathogenic microorganisms. Kasetsart Journal (Natural Science), 37, 460-467. http://www.rdi.ku.ac.th/KU_Journal/Sciences/doc/KU37(4).pdf\#page=76. Accessed 18 Dec 2015.

Madaan, S., \& Madaan, T. R. (1985). Speman in oligospermia. Probe, 24(2), 115-117. Accessed at http://himalayacen troamericana.com/himalaya_researchpapers/pdf_files/speman058.pdf.

Madan, H., Gogia, S., \& Sharma, S. (2011). Antimicrobial and spermicidal activities of Parthenium hysterophorus Linn. and Alstonia scholaris Linn. Indian Journal of Natural Products and Resources, 2(4), 458-463. http://nopr.niscair.res.in/ bitstream/123456789/13345/1/IJNPR\%202(4)\%20458-463.pdf. Accessed 23 Dec 2015.

Madhu, C., \& Ramanjaneyulu, M. (2013). Evaluation phytochemical screening, analgesic and antiinflammatory activity (synergic activity) of hydroalcoholic extract of Cocciniagrandis. International Journal of Pharma and Bio Sciences, 4(4), 180-186.

Maity, T. K., Mandal, S. C., Mukharjee, P. K., Saha, K., Das, J., et al. (1998). Studies on anti-inflammatory effect of Cassia tora leaf extract (fam. Leguminosae). Phytotherapy Research, 12, 221-223.

Malalavidhane, T. S., Wickramasinghe, S. N., \& Jansz, E. R. (2000a). Oral hypoglycaemic activity of Ipomoea aquatica. Journal of Ethnopharmacology, 72(1), 293-298. doi:10.1016/50378-8741(00)00217-8.

Malalavidhane, T. S., Wickramasinghe, S. N., \& Jansz, E. R. (2000b). Oral hypoglycaemic activity of Ipomoea aquatica. Journal of Ethnopharmacology, 72(1), 293-298. doi:10.1016/50378-8741(00)00217-8.

Malhotra, S. K., \& Moorthy, S. (1973). Some useful \& medicinal plants or Chandrapur district (Maharashtra State). Bull. Bot. Surv. India, 15, 13-21.

Malhotra, S. P., Dutta, B. K., Gupta, R. K., \& Gaur, Y. D. (1966). Medicinal plants of the Indian arid zone. Journal D'agriculture Tropicale et de Botanique Appliquée, 13(6-7), 247-288. doi:10.3406/jatba.1966.2885.

Mali, R. G. (2010). Cleome viscosa (wild mustard): A review on ethnobotany, phytochemistry, and pharmacology. Pharmaceutical Biology, 48(1), 105-112. doi:10.3109/13880200903114209 https:/www.researchgate.net/profile/G_ LEELAPRAKASH/publication/215806094_Invitro_antimicrobial_and_antioxidant_activity_of_Momordica_charantia_ leaves/links/04325252bbcfedaeb9857001.pdf. Accessed 23 Dec 2015.

Manda, H., Rao, B. K., Yashwant, G. N., \& Swarnkar, S. K. (2009). Antioxidant, Anti-Inflammatory and Antipyretic Activities of Ethyl Acetate Fraction of Ethanolic Extract of Schrebera swietenioides Roxb. Root. International Journal of Toxicological and Pharmacological Research, 1,7-11.

Mandal, S. C., Maity, T. K., Das, J., Pal, M., \& Saha, B. P. (1999). Hepatoprotective activity of Ficus racemosa leaf extract on liver damage caused by carbon tetrachloride in rats. Phytotherapy Research, 13(5), 430-432. doi:10.1002/(SICI)10991573(199908/09)13:5<430::AID-PTR456>3.0.CO;2-G.

Mangathayaru, K., Umadevi, M., \& Reddy, C. U. (2009). Evaluation of the immunomodulatory and DNA protective activities of the shoots of Cynodon dactylon. Journal of Ethnopharmacology, 123(1), 181-184. doi:10.1016/j.jep.2009.02.036.

Manjula, R. R., Rao, J. K., \& Reddi, T. S. (2013). Ethnomedicine for rheumatism by the tribals of Khammam District, Andhra Pradesh. Journal of Natural Remedies, 13(2), 138-141.

Marwat, S. K., \& Khan, I. U. (2015). Ethnobotanical Importance and Phytochemical constituents of Parthenium weed (Parthenium hysterophorus L.)-A Review. Plant Science Today, 2(2), 77-81. doi:10.14719/pst.2015.2.2.113.

Mathad, P., \& Mety, S. S. (2010). Phytochemical and Antimicrobial Activity of Digera Muricata (L.) Mart. Journal of Chemistry, 7(1), 275-280 Access at downloads.hindawi.com.

Mbazima, V. G., Mokgotho, M. P., February, F., Rees, D. J. G., \& Mampuru, L. J. M. (2008). Alteration of Bax-to-Bcl-2 ratio modulates the anticancer activity of methanolic extract of Commelina benghalensis (Commelinaceae) in Jurkat T cells. African Journal of Biotechnology, 7(20), 3569-3576. http://www.ajol.info/index.php/ajb/article/view/59373/47672. Accessed 20 Dec 2015.

Meena, H., Pandey, H. K., Pandey, P., Arya, M. C., \& Ahmed, Z. (2012). Evaluation of antioxidant activity of two important memory enhancing medicinal plants Baccopa monnieri and Centella asiatica. Indian Journal of Pharmacology, 44(1), 114.

Mehrotra, N. N., Ojha, S. K., \& Tandon, S. (2007). Drug development for cardiovascular diseases from ayurvedic plants. Feature, 1, 89. Accessed at http://www.cdriindia.org/R\%26D1-3full.pdf.

Mehta, J. P., \& Vadia, S. H. (2014). In-vitro antioxidant activity and antibacterial assay of minor millet extracts. Journal of Chemical and Pharmaceutical Research, 6(7), 2343.

Mehta, K., Balaraman, R., Amin, A. H., Bafna, P. A., \& Gulati, O. D. (2003). Effect of fruits of Moringa oleifera on the lipid profile of normal and hypercholesterolaemic rabbits. Journal of Ethnopharmacology, 86(2), 191-195. doi:10.1016/ S0378-8741(03)00075-8.

Mishra, K., Dash, A. P., Swain, B. K., \& Dey, N. (2009). Anti-malarial activities of Andrographis paniculata and Hedyotis corymbosa extracts and their combination with curcumin. Malaria Journal, 8(1), 26. doi:10.1186/1475-2875-8-26.

Mishra, M. K., Tiwari, P., Dash, D. K., Jadon, R. S., Ghosh, G., \& Barik, B. B. (2010). Antifungal activity of Leptadenia reticulata Wight and Arn. aerial parts. International Journal of Phytomedicine, 2(2), 172-176.

Mishra, R., Mishra, P., \& Ahmad, S. (2012). A Review on Herbal Treatment Of Obesity. International Journal of Pharmaceutical and Chemical Science, 1, 523-525. http://www.ijpcsonline.com/files/9-79.pdf. Accessed 27 Dec 2015.

Mistry, et al. (2014). Invitro-antioxidant, anti-inflammatory and anti proliferative activity of crude extract of Bacopamonnieri. World Journal of Pharmacy and Pharmaceutical Sciences, 11(3), 646-662. Accessed at wjpps.com/ download/article/1414819302.pdf. 
Mohammed, H. K. P., Anu, A., Saraswathi, R., Guru, P. M., \& Chandini, N. (2012). Formulation and Evaluation of Herbal Gel of Basella alba for wound healing activity. Journal of Pharmaceutical Sciences and Research, 4(1), 1642-1648. Accessed at https://pdfs.semanticscholar.org/9b5a/0c15847887a84a366e39923725dbca78b958.pdf.

Mohan K and Singh A. K. Advances in Plant Science, Ethno-medico-botany of Tharus, 9: 1-6, 1996

Mohd, J. K., Vipin, S., Varun, S. B., Manvendra, S. K., \& Sanjay, B. K. (2011). Anxiolytic activity of Ipomoea aquatica leaves. Eur J Exp Biol, 1, 63-70 Accessed at. http://pelagiaresearchlibrary.com/european-journal-of-experimental-biology/ vol1-iss1/EJEB-2011-1-1-63-70.pdf. Accessed 4 Dec 2015.

Moore, M.L. \& Westley, F. (2011). Surmountable chasms: networks and social innovation for resilient systems. Ecology and Society, 16(1).

Morais, S. M. D., Dantas, J., Silva, A. R. A. D., \& Magalhães, E. F. (2005). Ethno-medicinal plants of Tapeba Indians from the State of Ceará-Brazil. Revista Brasileira de Farmacognosia, 15(2), 169-177.

Mulgan, G. (2006). The process of social innovation. Innovations, 1(2), 145-162.

Mulla, W. A., Chopade, A. R., Bhise, S. B., Burade, K. B., \& Khanwelkar, C. C. (2011). Evaluation of antidiarrheal and in vitro antiprotozoal activities of extracts of leaves of Alocasia indica. Pharmaceutical Biology, 49(4), 354-361. doi:10.3109/13880209.2010.517211.

Mulla, W. A., Kuchekar, S. B., Thorat, V. S., Chopade, A. R., \& Kuchekar, B. S. (2010). Antioxidant, Antinociceptive Antiinflammatory Activities of Ethanolic Extract of Leaves of Alocasia indica (Schott.) Journal of Young Pharmacists, 2(2), 137-143. doi:10.4103/0975-1483.63152.

Mulla, W. A., Salunkhe, V. R., \& Bhise, S. B. (2009). Hepatoprotective activity of hydroalcoholic extract of leaves of Alocasia indica (Linn.) Indian Journal of Experimental Biology, 47(10), 816 ISSN: 0975-1009 (Online).

Mulla, W. A., Salunkhe, V. R., Kuchekar, S. B., \& Qureshi, M. N. (2009). Free radical scavenging activity of leaves of Alocasia indica (Linn). Indian Journal of Pharmaceutical Sciences, 71(3), 303. doi:10.4103/0250-474X.56036. Accessed at http:// www.ncbi.nlm.nih.gov/pmc/articles/PMC2865790/.

Murakami, A., Kitazono, Y., Jiwajinda, S., Koshimizu, K., \& Ohigashi, H. (1998). Niaziminin, a thiocarbamate from the leaves of Moringaoleifera, holds a strict structural requirement for inhibition of tumor-promoter- induced Epstein-Barr virus activation. Planta Medica, 64, 319-323.

Muthul, C., Muniappan, A., Nagappan, R., \& Savarimuthu, I. (2006). Medicinal plants used by traditional healers in Kancheepuram District of Tamil Nadu. Journal of Ethnobiology and Ethnomedicine, 2, 43-52 ISSN: 1746-4269.

Nadkarni, K. M. (1976). Indian materia medica with ayurvedic, unani-tibbi, siddha, allopathic, homeopathic, naturopathic \& home remedies, appendices \& indexes. Popular Prakashan: Bombay.

Nagarjuna, S., Murthy, T. G. K. \& Rao, A. S. (2015). Antidiabetic Activity of Different Fractions of Ethanolic Extract of Dactyloctenium aegyptium in Streptozotocin Induced Diabetic Rats. 8(4): 1-10. http://crawl.prod.proquest.com.s3.amazonaws.com/fpcache/ 4b2cfb8e3e320b8f3baaa3fa27c01 ce5.pdf?AWSAccessKeyld=AKIAJF7V7KNV2KKY2NUQ\&Expires=1454090775 \&Signature=dmzASo\%2BJYb4QUzrRimwQfRSt\%2Byo\%3D. Accessed 13 Dec 2015.

Nagulendran, K. R., Velavan, S., Mahesh, R., \& Begum, V. H. (2007). In vitro antioxidant activity and total polyphenolic content of Cyperus rotundus rhizomes. Journal of Chemistry, 4(3), 440-449 ISSN: 0973-4945.

Nahar, N. (1993). Traditionalmedicine (18th ed.pp. 205-209). NewDelhi: Oxford and OBH Publishing Co. Pvt. Ltd.

Nair, R., Kalariya, T., \& Chanda, S. (2005). Antibacterial Activity of Some Selected Indian Medicinal Flora. Journal of Biology Turkey, 29, 41-47. http://journals.tubitak.gov.tr/biology/issues/biy-05-29-1/biy-29-1-7-0405-4.pdf. Accessed 6 Dec 2015.

Najafi, M., Nazemieh, H., Ghavimi, H., Gharahkhani, A., \& Garjani, A. (2009). Effects of Hydroalcoholic Extract Of Cynodon Dactylon (L.)PERS. Rhizome On Infarct Size In Ischemic Isolated Heart, 14(4), 267-273.

Najafi, M., Nazemiyeh, H., Garjani, A., Ghavimi, H., \& Gharekhani, A. (2007). Cardioprotective effects of Cynodon Dactylon against ischemia/reperfusion-induced arrhythmias. Journal of Molecular and Cellular Cardiology, 42(6), S12.

Nambiar, V. P. K. (1996). Indian medicinal plants: a compendium of 500 species (Vol. 5). Orient Blackswan ISBN: 8125007636,9788125007630

Nanasombat, S., \& Teckchuen, N. (2009). Antimicrobial, antioxidant and anticancer activities of Thai local vegetables. J Med Plants Res, 3(5), 443-449. http://www.academicjournals.org/journal/JMPR/article-full-text-pdf/A854CB115293. Accessed 18 Dec 2015.

Narayanasamy, R. \& Leelavinothan, P. (2011). In-vivo and in-vitro antioxidant activities of coumarin on chemical induced hyperglycemic rats. International Journal of Pharmaceutical Sciences and Research, 2(4), 968-978.

Natarajan, A., Leelavinodh, K. S., Jayavelu, A., Devi, K., \& Kumar, B. S. (2013). A study on ethnomedicinal plants of Kalavai, Vellore District, Tamil Nadu, India. 3(1): 99-102. DOI: 10.7324/JAPS.2013.30119. Accessed at http://imsear.li.mahidol. ac.th/bitstream/123456789/151516/1/japs2013v3n1p99.pdf

Negi, B. S., Dave, B. P., \& Agarwal, Y. K. (2012). Evaluation of antimicrobial activity of Bauhinia purpurea leaves under in vitro conditions. Indian Journal of Microbiology, 52(3), 360-365. doi:10.1007/s12088-012-0264-0.

Nema, A. K., Agarwal, A., \& Kashaw, V. (2011). Hepatoprotective activity of Leptadenia reticulata stems against carbon tetrachloride-induced hepatotoxicity in rats. Indian Journal of Pharmacology, 43(3), 254. doi:10.4103/0253-7613.81507.

Niazi, J., Singh, P., Bansal, Y., \& Goel, R. K. (2009). Anti-inflammatory, analgesic and antipyretic activity of aqueous extract of fresh leaves of Coccinia indica. Inflammopharmacology, 17(4), 239-244. doi:10.1007/s10787-009-0010-3.

Nikolajsen, T., Nielsen, F., Rasch, V., Sørensen, P. H., Ismail, F., Kristiansen, U., \& Jäger, A. K. (2011). Uterine contraction induced by Tanzanian plants used to induce abortion. Journal of Ethnopharmacology, 137(1), 921-925. doi:10.1016/j.jep.2011.05.026.

Nima, Z. A., Jabier, M. S., Wagi, R. I., \& Hussain, H. A. (2008). Extraction, Identification and Antibacterial activity of Cyperus oil from Iraqi C. rotundus. Engineering and Technology, 26(10), 1156-1160.

Nisar, M. F., et al. (2014). Ethno-medicinal uses of plants from district Bahawalpur, Pakistan. Curr Res J BiolSci, 6(5), 183190 ISSN: 0975-5071.

Odenigbo, G. O., \&Awachie, P. I. (1993). Anticonvulsant activity of aqueous ethanolic extract of Cynodondactylon. 64(5), 447-449. Accessed at http://wwwlib.teiep.gr/images/stories/acta/Acta\%20680/680_16.pdf

Okello, J., \& Ssegawa, P. (2007). Medicinal plants used by communities of Ngai Subcounty, Apac District, northern Uganda. African Journal of Ecology, 45(s1), 76-83. doi:10.1111/j.1365-2028.2007.00742.x.

Paarakh, P. M. (2009). Ficus racemosa linn.-an overview. Natural Product Radiance, 8(1), 84-90. http://nopr.niscair.res.in/ bitstream/123456789/3777/1/NPR\%208(1)\%2084-90.pdf. Accessed 2 Dec 2015. 
Padmalatha, K., Venkataraman, B. V., \& Roopa, R. (2002). Antianaphylactic effect of DLH-3041 (polyherbal formulation) on rat mesenteric mast cell degranulation. Indian Journal of Pharmacology, 34(2), 119-122. Accessed at http://medind. nic.in/ibi/t02/i2/ibit02i2p119.pdf on December 27, 2015.

Pal, D. K. (2009). Determination of brain biogenic amines in Cynodon dactylon pers. and Cyperus rotundus treated mice. International Journal of Pharmacy and Pharmaceutical Sciences, 1(1), 190-197. http://ijppsjournal.com/ Vol\%201\%20lssue\%201/134.pdf. Accessed 14 Dec 2015.

Palani, S., Raja, S., Karthi, S., Archana, S., \& Kumar, B. S. (2010). In vivo analysis of nephro \& hepato protective effects and antioxidant activity of Madhuca longifolia against acetaminophen-induced toxicity \& oxidative stress. Journal of Pharmacy Research, 3(1), 9-16.

Pareek, A. (1994). Preliminary ethnobotanical notes on the plants of aquatic habitats of Rajasthan. Journal of Phytolological Research, 7, 73-76.

Pari, L., \& Maheshwari, U. J. (2000). Antihyperglycemic activity of Musa sapientum flowers: effect on lipid peroxidation in alloxan diabetic rats. Phytotherapy Research, 14, 136-138. doi:10.1002/(SICI) 1099-1573(200003)14:2<136:AID-PTR607>3.0.CO;2-K.

Pari, L., \& Kumar, N. A. (2002). Hepatoprotective activity of Moringa oleifera on antitubercular drug-induced liver damage in rats. Journal of Medicinal Food, 5(3), 171-177. doi:10.1089/10966200260398206.

Parul, B. D., \& Vashistha. (2015). An Ethnobotanical Study of Plains of Yamuna Nagar District, Haryana, India. International Journal of Innovative Research in Science, Engineering and Technology, 4(1). http://www.ijirset.com/upload/2015/ january/36_An.pdf. Accessed 23 Dec 2015.

Patel, J. R., Tripathi, P., Sharma, V., Chauhan, N. S., \& Dixit, V. K. (2011). Phyllanthus amarus: ethnomedicinal uses, phytochemistry and pharmacology: a review. Journal of Ethnopharmacology, 138(2), 286-313. doi:10.1016/j.jep.2011.09.040.

Patel, R. P., \& Dantwala, A. S. (1958). Antimicrobial activity of Leptadenia reticulata. The Indian Journal of Pharmacy, 20, 241-244.

Patel, T., Shah, K., Jiwan, K., \& Shrivastava, N. (2011). Study on the antibacterial potential of Physalis minima Linn. Indian Journal of Pharmaceutical Sciences, 73(1), 111. doi:10.4103/0250-474X.89770.

Patil, B. R., \& Ageely, H. M. (2011a). Antihepatotoxic activity of Colocasia esculenta leaf juice. International Journal of Advanced Biotechnology and Research, 2, 296-304. https:/www.researchgate.net/profile/Bhagyashree_Patil/ publication/259176624_IJABRv2i22011011/links/Odeec52a1ffca51a2b000000.pdf. Accessed 5 Dec 2015.

Patil, B. R., \& Ageely, H. M. (2011b). Anti-lipid peroxidative activity of Colocasiaesculenta leaf juice against CCL 4 and acetaminophen mediated cell damage. International Journal of Pharmaceutical Applications, 2(3), 141-149.

Patil, M. B., Jalalpure, S. S., Prakash, N. S., \& Kokate, C. K. (2003a). Antiulcer properties of alcoholic extract of Cynodon dactylon in rats. In III WOCMAP Congress on Medicinal and Aromatic Plants-Volume 6: Traditional Medicine and Nutraceuticals 680 (pp. 115-118).

Patil, M. B., Jalalpure, S. S., Prakash, N. S., \& Kokate, C. K. (2003b). Antiulcer properties of alcoholic extract of Cynodon dactylon in rats. In III WOCMAP Congress on Medicinal and Aromatic Plants-Vol 6: Traditional Medicine and Nutraceuticals 680 (pp. 115-118). doi:10.17660/ActaHortic.2005.680.16.

Patil, S. H., Sreenivas, S. A., Deshmukh, P. V., Srikanth, M., Choudhury, A., \& Wagh, A. E. (2012). Antidiabetic \& hypolipidemic potential of Alocasia indica Schott. Leaves in Streptozotocin induced diabetic rats. International Journal of Drug Development \& Research, 4, 368-374.

Patil, V. V., Bhangale, S. C., Chaudhari, K. P., Kakade, R. T., Thakare, V. M., Bonde, C. G., \& Patil, V. R. (2012). Evaluation of the antidiarrheal activity of the plant extracts of Ficus species. Journal of Chinese Integrative Medicine, 10(3), 347-352. http://www.jcimjournal.com/articles/publishArticles/pdf/jcim20120315.pdf. Accessed 14 Dec 2015.

Paul, D., De, D., Ali, K. M., Chatterjee, K., Nandi, D. K., \& Ghosh, D. (2010). Comparative study on the spermicidal activity of organic solvent fractions from hydroethanolic extracts of Achyranthes aspera and Stephania hernandifolia in human and rat sperm. Contraception, 81(4), 355-361. doi:10.1016/j.contraception.2009.09.001.

Paulsson, B., Granath, F., Grawe, J., Ehrenberg, L., \& Törnqvist, M. (2001). The multiplicative model for cancer risk assessment: applicability to acrylamide. Carcinogenesis, 22(5), 817-819. doi:10.1093/carcin/22.5.817.

Perry, L. M., \& Metzger, J. (1980). Medicinal plants of east and southeast Asia: attributed properties and uses (p. 620). Cambridge: MIT press.

Pingali, P.S., Srinivas, P. \& Reddy M.B. (2015). Study of anti-anaemic effect of Schrebera swietenioides roxb: in rat models. Asian Journal of Pharmaceutical and Clinical Research, 8(5), 260-263.

Poonkothai, M., \& Saravanan, M. (2008). Ancient Science of Life, 17, 15-18.

Prabhu, A., Krishnamoorthy, M., Prasad, D. J., \& Naik, P. (2013). Anticancer Activity of Friedelin Isolated from Ethanolic Leaf Extract of Cassia tora on HeLa and HSC-1 Cell Lines. Indian J. Appl. Res, 3(10), 1-4.

Prahalad, C. K. (2006). The Fortune at the Bottom of the Pyramid. Pearson Education India

Prajapati, V., Tripathi, A. K., Khanuja, S. P. S., \& Kumar, S. (2003). Anti-insect screening of medicinal plants from Kukrail Forest, Lucknow, India. Pharmaceutical Biology, 41(3), 166-170. doi:10.1076/phbi.41.3.166.15092.

Prakash, A. O., \& Mathur, R. (1976). Screening of Indian plants for antifertility activity. Indian Journal of Experimental Biology, 14(5), 623-626.

Prasad, S., Kashyap, R. S., Deopujari, J. Y., Purohit, H. J., Taori, G. M., \& Daginawala, H. F. (2006). Development of an in vitro model to study clot lysis activity of thrombolytic drugs. Thrombosis Journal, 4(14), 1-4. doi:10.1186/14779560-4-14. http://download.springer.com/static/pdf/901/art\%253A10.1186\%252F1477-9560-4-14.pdf?originUrl= http\%3A\%2F\%2Fthrombosisjournal.biomedcentral.com\%2Farticle\%2F10.1186\%2F1477-9560-4-14\&token2=exp= 1454050206 acl=\%2Fstatic\%2Fpdf\%2F901\%2Fart\%25253A10.1186\%25252F1477-9560-4-14.pdf* $\sim$ hmac $=$ 1f35bcd2b97b4b2eb6f57547ef4400efffda23ba2c51027df7edf646303f71ed. Accessed 18 Dec 2015.

Prashanth, S., Kumar, A. A.r Madhu, B., Kumar, Y. P., \& Prashanth, S. (2010). Antihyperglycemic and antioxidant activity. of ethanolic extract of madhuca longifolia bark. International Journal of Pharmaceutical Sciences Review and Research, 5(3), 89-94.

Priya, S., \& Jenifer, S. (2014). Antibacterial Activity of Leaf and Flower Extract of Lablab purpureus against Clinical Isolates of Staphylococcus aureus. Research \& Reviews: A Journal of Drug Design \& Discovery, 1(2), 5-7 ISSN: 2349-9036.

Puratchikody, A., Devi, C. N., \& Nagalakshmi, G. (2006). Wound healing activity of cyperus rotundus linn. Indian Journal of Pharmaceutical Sciences, 68(1), 97. doi:10.4103/0250-474X.22976. 
Qu, M., Xu, H., Li, Y., \& Luo, H. (1990). An illustrated guide to antineoplastic Chinese herbal medicine. The Commercial, 144-145.

Rahman, G. M. S., Haque, N., \& Rashid, A. (1990). Cytotoxic activity of Commelina benghalensis Linn. using Brine Shrimp Lethality Bioassay. Bang J Physiol Pharmacol, 15, 62-65.

Rahman, A. M. (2014). Ethno-gynecological study of traditional medicinal plants used by santals of Joypurhat District, Bangladesh. Biomedicine and Biotechnology, 2(1), 10-13. doi:10.12691/bb-2-1-2. Accessed at file:///C:/Users/IMA/ Downloads/bb-2-1-2.pdf.

Rahman, M. M., Sheikh, M. M. I., Sharmin, S. A., Islam, M. S., Rahman, M. A., Rahman, M. M., \& Alam, M. F. (2009). Antibacterial activity of leaf juice and extracts of Moringa oleifera Lam. against some human pathogenic bacteria. CMU J Nat Sci, 8(2), 219. http://www.researchmoringa.com/uploads/3CMU_J_Nat_Sci_Antibacterial_Activity.pdf. Accessed 22 Dec 2015.

Rahmatullah, M., Islam, M. R., Kabir, M. Z., Harun-or-Rashid, M., Jahan, R., Begum, R., et al. (2010). Folk medicinal practices in Vasu Bihar village, Bogra district, Bangladesh. American-Eurasian Journal of Sustainable Agriculture, 4(1), 86-93 ISSN: 1995-0748. https://www.researchgate.net/profile/Md_Islam174/publication/264741946_Folk_Medicinal_ Practices_in_Vasu_Bihar_Village_Bogra_District_Bangladesh/links/53ed38310cf2981ada15a34b.pdf.

Rahmatullah, M., Mollik, M. A. H., Azam, A. T. M. A., Islam, M. R., Chowdhury, M. A. M., Jahan, R., et al. (2009). Ethnobotanical survey of the Santal tribe residing in Thakurgaon District, Bangladesh. American Eurasian Journal of Sustainable Agriculture, 3(4), 889-898. ISSN: 1995-0748. Accessed at https://www.researchgate.net/profile/Majeedul_ Chowdhury/publication/228669239_Ethnobotanical_Survey_of_the_Santal_tribe_residing_in_Thakurgaon_District_ Bangladesh/links/09e4150875d8d7b2a4000000.pdf.

Rahmatullah, M., Rahman, M. A., Haque, M. Z., Mollik, M. A., Miajee, Z. U. M. E. U., Begum, R., et al. (2010). A survey of medicinal plants used by folk medicinal practitioners of Station Purbo Para village of JamalpurSadarUpazila in Jamalpur district, Bangladesh. American-Eurasian Journal of Sustainable Agriculture, 4(2), 122-135. ISSN: 1995-0748.

Rajan, S., Gokila, M., Jency, P., Brindha, P., \& Sujatha, R. K. (2011). Antioxidant and phytochemical properties of Aegle marmelos fruit pulp. International Journal of Current Pharmaceutical Research, 3(2), 6. Accessed at http://www.ijcpr. org/lssues/Nol3lssue2/306.pdf. Accessed 22 Dec 2015.

Rajasab, A. H., \& Isaq, M. (2004). Documentation of folk knowledge on edible wild plants of North Karnataka. Indian Journal of Traditional Knowledge, 3(4), 419-429. http://nopr.niscair.res.in/bitstream/123456789/9377/1/ IJTK\%203(4)\%20419-429.pdf. Accessed 21 Dec 2015.

Raman, A., \& Lau, C. (1996). Anti-diabetic properties and phytochemistry of Momordica charantia L.(Cucurbitaceae). Phytomedicine, 2(4), 349-362. doi:10.1016/50944-7113(96)80080-8.

Ramu, G., Krishna Mohan, G., Jayaveera, K. N., Ramu, G., Mohan, G. K., \& Jayaveera, K. N. (2011). Preliminary investigation of patchaippasali mucilage (Basellaalba) as tablet binder. International Journal of Green Pharmacy, 5(1), 24-27.

Rao, B., Ojha, K. V., Preeti, V., Kumar, G., \& Karthik, L. (2014). Phytochemical Composition and Antioxidant Activity of Ficus benghalensis (Moraceae) Leaf Extract. Journal of Biologically Active Products from Nature, 4(3), 236-248. doi:10.1080/ 22311866.2014 .936902$.

Rao, C. V., Ojha, S. K., Amresh, G., Mehrotra, S., \& Pushpangadan, P. (2003). Analgesic, antiinflammatory and antiulcerogenic activity of unripe fruits of Aegle marmelos. Acta Pharmaceutica Turcica, 45, 85-91.

Rejiya, C. S., Cibin, T. R., \& Abraham, A. (2009). Leaves of Cassia tora as a novel cancer therapeutic-an in vitro study. Toxicology In Vitro, 23(6), 1034-1038. doi:10.1016/j.tiv.2009.06.010.

Rekha, D., \& Shivanna, M. B. (2014). Diversity, antimicrobial and antioxidant activities of fungal endophytes in Cynodon dactylon (L.) Pers. and Dactyloctenium aegyptium (L.) P. Beauv. International Journal of Current Microbiology and Applied Sciences, 3(8), 573-591. http://www.ijcmas.com/vol-3-8/D.Rekha\%20and\%20M.\%20B.\%20Shivanna.pdf. Accessed 12 Dec 2015.

Riga. (2017). SOIMTC Conference.

Roitt, l., Grostoff, J., \& Male, D. (1998). Immunology. London: Mosbypublication.

Roy, A., Bhattacharya, S., Pandey, J. N., \& Biswas, M. (2011). Anti-inflammatory activity of Syzygiumcumini leaf against experimentally induced acute and chronic inflammations in rodents. Alternative Medicine Studies, 1(1), 6. doi:10.4081/ams.2011.e6. Accessed at https://docs.google.com/viewerng/viewer?url=http://www.pagepress.org/ journals/index.php/ams/article/viewFile/ams.2011.e6/pdf.

Ruddon, R. W. (2007). Cancer biology (3rd ed.). Newyork: Oxford University Press ISBN: 0195175433.

Sahni, S., Maurya, S., Singh, U. P., Singh, A. K., Singh, V. P., \& Pandey, V. B. (2005). Antifungal activity of nor-securinine against some phytopathogenic fungi. Mycobiology, 33(2), 97-103 http://dx.doi.org/10.4489/MYCO.2005.33.2.097.

Saluja, M. S., Sangameswaran, B., Hura, I. S., Sharma, A., Gupta, S. K., \& Chaturvedi, M. (2011). In Vitro cytotoxic activity of leaves of Madhuca longifolia against Ehrlich Ascites Carcinoma (EAC) cell lines. International Journal of Drug Discovery and Herbal Research (IJDDHR), 1(2), 55-57. http://scholarsresearchlibrary.com/JNPPR-vol1-iss4/JNPPR-20111-4-66-72.pdf. Accessed 25 Nov 2015. ISSN: 2231-3184.

Sambrekar Sudhir, N., et al. (2013). Protective Effects Of Commelina Benghalensis Linn (Root) Extract On Ethanol Induced Acute Hepatotoxicity In Rats. IJSIT, 2(3), 172-183. http://www.ijsit.com/admin/ijsit_files/ PROTECTIVE\%20EFFECTS\%20OF\%20COMMELINA\%20BENGHALENSIS\%20LINN\%20(ROOT)\%20EXTRACT\%200N \%20ETHANOL\%20INDUCED\%2OACUTE\%20HEPATOTOXICITY\%20IN\%20RATS_IJSIT_2.3.1.pdf. Accessed 8 Dec 2015.

Samuelsson, G., Farah, M. H., Claeson, P., Hagos, M., Thulin, M., Hedberg, O., et al. (1992). Inventory of plants used in traditional medicine in Somalia. II. Plants of the families Combretaceae to Labiatae. Journal of Ethnopharmacology, 37(1), 47-70. doi:10.1016/0378-8741(92)90004-B.

Sankaranarayanan, S., et al. (2010). Ethnobotanical study of medicinal plants used by traditional users in Villupuram district of Tamil Nadu, India. J Med Plants Res, 4(12), 1089-1101. https:/www.researchgate.net/profile/Puthupalayam_Kalaichelvan/ publication/266408827_Ethnobotanical_study_of_medicinal_plants_used_by_traditional_users_in_Villupuram_district_ of_Tamil_Nadu_India/links/54b207640cf220c63cd12ae2.pdf. Accessed 17 Dec 2015.

Santos, A. R., Valdir Filho, C., Yunes, R. A., \& Calixto, J. B. (1995). Further Studies on the Antinociceptive Action of the Hydroalcoholic Extracts from Plants of the Genus, Phyllanthus. Journal of Pharmacy and Pharmacology, 47(1), 66-71. doi:10.1111/j.2042-7158.1995.tb05736.x. 
Sasikumar, J. M., Maheshu, V., Aseervatham, G., \& Darsini, D. (2010). In vitro antioxidant activity of Hedyotis corymbosa (L.) Lam. aerial parts. Indian Journal of Biochemistry \& Biophysics, 47, 49-52. http://imsear.li.mahidol.ac.th/bitstream/ 123456789/135243/1/ijbb2010v47n1p49.pdf. Accessed 17 Dec 2015.

Sathis Kumar, D., Banji, D., \& Harani, A. (2013). Antihypercholesterolemic effect of echinochloa crusgalli extract. International Journal of Pharma Sciences. ISSN: 2320-6810. http:/ijps.aizeonpublishers.net/content/2013/ conference_abstracts/69A.pdf. Accessed 4 Dec 2015.

Sathiyanarayanan, L., Sinnathambi, A., \& Chidambaranathan, A. (2007). Anticarcinogenic activity of Leptadenia reticulata against Daltons ascitic lymphoma. Iranian Journal of Pharmacology and Therapeutics, 6(2), 133-135.

Saturnino, C., Fusco, B., Saturnino, P., Martino, G. D., Rocco, F., \& Lancelot, J. C. (2000). Evaluation of Analgesic and Antiinflammatory Activity of Novel. BETA.-Lactam Monocyclic Compounds. Biological and Pharmaceutical Bulletin, 23(5), 654-656. http://www.interscience.org.uk/index.php/ijcc/article/view/51. Accessed 15 Dec 2015.

Savali, A. S., Bhinge, S. D., \& Chitapurkar, H. R. (2011). Evaluation of hair growth promoting activity of Musa paradisiaca unripe fruit extract. Journal of Natural Pharmaceuticals, 2(3), 120-124. doi:10.4103/2229-5119.86257.

Sawant, M., Isaac, J. C., \& Narayanan, S. (2004). Analgesic studies on total alkaloids and alcohol extracts of Eclipta alba (Linn.) Hassk. Phytotherapy Research, 18(2), 111-113. doi:10.1002/ptr.1165.

Saxena, B. R., Koli, M. C., \& Saxena, R. C. (2000). Preliminary ethnomedical and phytochemical study of Cleome viscosa L. Ethnobotany, 12, 47-50.

Schmelzer, G. H., \& Gurib-Fakim, A. (2013). Medicinal plants 2. Prota, 2, 158-159 ISBN: $9290815205,9789290815204$.

Schmelzer, G. H., \& Gurib-Fakim, A. (2008). Medicinal plants. PROTA, 1, 384 pages.

Shah, Amin, et al. (2013a). Ethnobotanical study of medicinal plants of semi-tribal area of Makerwal \& Gulla Khel (lying between Khyber Pakhtunkhwa and Punjab Provinces), Pakistan. DOl:10.4236/ajps.2013.41015.

Shah, A., et al. (2013b). Ethnobotanical study of medicinal plants of semi-tribal area of Makerwal \& Gulla Khel (lying between Khyber Pakhtunkhwa and Punjab Provinces). Pakistan., 4(1). doi:10.4236/ajps.2013.41015.

Shaikh, T., Rub, R., \& Bhise, K. (2010). Antibacterial activity of Ficus racemosa Linn. Leaves on Actinomyces viscosus. Journal of Pharmaceutical Sciences and Research, 2(1), 41-44. http://citeseerx.ist.psu.edu/viewdoc/download?doi=10. 1.1.296.7993\&rep=rep1\&type=pdf. Accessed 17 Dec 2015.

Shanbhag, T., Amuthan, A., \& Shenoy, S. (2010). Effect of Phyllanthus niruri. Linn on burn wound in rats. Asian Pacific Journal of Tropical Medicine, 3(2), 105-108. doi:10.1016/S1995-7645(10)60045-4.

Sharma, N., Tanwer, B. S., \& Vijayvergia, R. (2011). Study of medicinal plants in Aravali regions of Rajasthan for treatment of Kidney stone and Urinary tract troubles. International Journal of PharmTech Research, 3(1), 110-113. http://www.sphinxsai.com/Vol.3No.1/ppdf/pdf/JM11(PT=19)\%20pp\%20110-113.pdf. Accessed 26 Dec 2015.

Sharma, S., Sharma, M. C., \& Kohli, D. V. (2010). Wound healing activity and formulation of ether-benzene-95\% ethanol extract of herbal drug Madhuca longifolia leaves in albino rats. Journal of Optoelectronics and Biomedical Materials, 1(1), 13-15. Accessed at http://www.chalcogen.ro/13_Sharma.pdf.

Shazia, S., \& Sobiya, S. (2012). Biological Control Potential of Parthenium Hysterophorus Against Fusarium Solani- A Cause of Fusarium Wilt in Potato. In International Conference on Applied Life Sciences (pp. 315-320).

Shekhawat, N., \& Vijayvergia, R. (2010). Investigation of anti-Inflammatory, analgesic and antipyretic Properties of Madhuca indica GMEL. European Journal of Inflammation, 8(3), 165-171. doi:10.1177/1721727X1000800305.

Shen, H. D., Wang, S. R., Tang, R. B., Chang, Z. N., Su, S. N., \& Han, S. H. (1988). Identification of allergens and antigens of Bermuda grass (Cynodondactylon) pollen by immunoblot analysis. Clinical \& Experimental Allergy, 18(4), 401-409. doi:10.1111/j.1365-2222.1988.tb02888.x Accessed at http://www.readcube.com/articles/10.1111\%2Fj.1365-2222.1988. tb02888.x? r3_referer=wol\&tracking_action=preview_click\&show_checkout=1\&purchase_referrer=onlinelibrary.wiley. com\&purchase_site_license=LICENSE_EXPIRED.

Shokunbi, O. S., \& Odetola, A. A. (2008). Gastroprotective and antioxidant activities of Phyllanthus amarus extracts on absolute ethanol-induced ulcer in albino rats. Journal of Medicinal Plant Research, 2(10), 261-267. http://www. academicjournals.org/app/webroot/article/article1380526259_Shokunbi\%20and\%200detola.pdf. Accessed 21 Dec 2015.

Shortt, J. (1878). List of wild plants and vegetables used as food by people in famine times. Indian Forester, 3(3), 232-238.

Shukla, A. N., Srivastava, S., \& Rawat, A. K. S. (2010). An ethnobotanical study of medicinal plants of Rewa district, Madhya Pradesh. Indian Journal of Traditional Knowledge, 9(1), 191-202. http:/www.niscair.res.in/ sciencecommunication/ResearchJournals/rejour/ijtk/Fulltextsearch/2010/January\%202010/IJTK-Vol\%209(1)\%20january\%202010-\%20pp\%20191-202.htm. Accessed 15 Dec 2015.

Sies, H. (1997). Oxidative stress: oxidants and antioxidants. Experimental Physiology, 82(2), 291-295. doi:10.1113/ expphysiol.1997.sp004024.

Silja, V. P., Varma, K. S., \& Mohanan, K. V. (2008). Ethnomedicinal plant knowledge of the Mullu kuruma tribe of Wayanad district, Kerala. Indian Journal of Traditional Knowledge 7(4), 604-612. ISSN: 0972-5938. Accessed at http://nopr. niscair.res.in/bitstream/123456789/2389/1/IJTK\%207\%284\%29\%20604-612.pdf.

Singh, R., \& Sankar, C. (2012). Screening for anti-diabetic activity of the ethanolic extract of Dolichos lablab leaves. PhTechMed., 1, 177-180. Accessed at http://www.pharmtechmedica.com/upload/Screening\%20for\%20AntiDiabetic\%20Activity\%20of\%20the\%20Ethanolic\%20Extract\%20of\%20Dolichos\%20Lablab\%20Leaves.pdf.

Singh, A., Malhotra, S., \& Subban, R. (2008). Anti-inflammatory and analgesic agents from Indian medicinal plants. International Journal of Integrative Biology, 3(1), 57-72. http://www.classicrus.com/IIB/Arch/2008/1068.pdf. Accessed 14 Dec 2015.

Singh, P. B. (1993). Medicinal plants of Ayurvedic importance from Mandi district of Himachal Pradesh. Bulletin of Medicinal and Ethnobotanical Research, 14(3/4), 126-136.

Singh, P. B., \& Aswal, B. S. (1992). Medicinal plants of Himachal Pradesh used in Indian pharmaceutical industry. BMEBR, $13(3-4), 172-208$.

Singh, S. K., Rai, P. K., Jaiswal, D., \& Watal, G. (2008). Evidence-based critical evaluation of glycemic potential of Cynodon dactylon. Evidence-based Complementary and Alternative Medicine, 5(4), 415-420 http://dx.doi.org/10.1093/ecam/ nem044. 
Sinha, R. (2008). The silent innovators, One India, One People (pp. 15-17).

Sivaraj, A., Jenifa, B. P., Kavitha, M., Inbasekar, P., Senthilkumar, B., \& Panneerselvam, A. (2011). Antibacterial activity of Coccinia grandis leaf extract on selective bacterial strains. 1(7): 120-3. http://imsear.li.mahidol.ac.th/bitstream/ 123456789/150912/1/japs2011v1n7p120.pdf. Accessed 23 Dec 2015.

Sivarajan, V. V., \& Balachandran, I. (1994). Ayurvedic drugs and their plant sources. Oxford and IBH Publishing. 195-200. ISBN: 8120408284,9788120408289

Sivaraman, D., \& Muralidaran, P. (2008). Anti-ulcerogenic evaluation of the ethanolic extract of water spinach (Ipomoea aquatica Forsk) in aspirin ulcerated rats. Journal of Pharmacy Research, 1(2). http://jprsolutions.info/files/final-file54e08d9db6baf0.36419834.pdf. Accessed 23 Dec 2015.

Sivaraman, D., \& Muralidaran, P. (2010). Nootropic effect of Ipomoea aquatic Forsk in rat hippocampus. International Journal of PharmTech Research, 2, 476-479. http://sphinxsai.com/sphinxsaiVol_2No.1/PharmTech_Vol_2No.1/ PharmTech_Vol_2No.1PDF/PT=74\%20(475-479).pdf. Accessed 19 Dec 2015.

Sivaraman, D., Muralidaran, P., \& Kumar, S. S. (2010). Evaluation of anti-microbial and anti-inflammatory activity of methanol leaf extract of Ipomoea aquatica Forsk. Research Journal of Pharmaceutical, Biological and Chemical Sciences, 1(2), 258-264. ISSN: 0975-8585.

Sivasankari, B., Anandharaj, M., \& Gunasekaran, P. (2014). An ethnobotanical study of indigenous knowledge on medicinal plants used by the village peoples of Thoppampatti, Dindigul district, Tamilnadu, India. Journal of Ethnopharmacology, 153(2), 408-423. doi:10.1016/j.jep.2014.02.040.

Smith, W. K., \& Tushman, M. L. (2005). Managing strategic contradictions: A top management model for managing innovation streams. Organization Science, 16(5), 522-536.

Soraya, H., Moloudizargari, M., Aghajanshakeri, S., Javaherypour, S., Mokarizadeh, A., Hamedeyazdan, S., et al. (2015). Angiogenic effect of the aqueous extract of Cynodondactylon on human umbilical vein endothelial cells and granulation tissue in rat. DARU Journal of Pharmaceutical Sciences, 23(1), 10. doi:10.1186/s40199-015-0093-x Accessed at http://download.springer.com/static/pdf/916/art\%253A10.1186\%252Fs40199-015-0093-x.pdf?originUrl= http\%3A\%2F\%2Fdarujps.biomedcentral.com\%2Farticle\%2F10.1 186\%2Fs40199-015-0093-x\&token2=exp=145386 5997 acl=\%2Fstatic\%2Fpdf\%2F916\%2Fart\%25253A10.1 186\%25252Fs40199-015-0093-x.pdf* $\sim$ hmac=7a57171f5e7 dd569a473251607c0a0a22525c3bf67cf976831 bdba4caf8ddfd4.

St. Luke. (2007). Breast cancer Treatments (1st ed.pp. 107-108).

Subramanian, S., et al. (1986). Wound healing properties of Cynodondactylon and Pongamiaglabra (18th Annual Conference of Indian Pharmacol. Soc., Jan. 8-10, Abstract No. 119). Indian Journal of Pharmacology, 18(1), 19-60.

Sudhakaran, S., Ramanathan, B., \& Ganapathi, A. (1999). Antifertility effects of the petroleum ether extract of Physalis minima on female albino rats. Pharmaceutical Biology, 37(4), 269-272. doi:10.1076/phbi.37.4.269.5809.

Suguna, J., et al. (2015). Antimicrobial and Antioxidant Activity of the Leaf Extract of Basellaalba. ljppr.Human, 3(2), 66-77.

Sunita, M., \& Sarojini, P. (2013). Madhuca Lonigfolia (Sapotaceae): A Review of Its Traditional Uses and Nutritional Properties. International Journal of Humanities and Social Science Invention, 2(5): 30-36. ISSN (Online): 2319-7722, ISSN (Print): 2319-7714. Accessed at https://www.researchgate.net/profile/Sunita_Mishra2/publication/257536534_ Madhuca_Lonigfolia_\%28Sapotaceae\%29_A_review_of_its_traditional_uses_and_nutritional_proporties/links/ Odeec536c82cecle54000000.pdf

Surendra, V., Prakash, T., Sharma, U. R., Goli, D., Fadadu, S. D., \& Kotresha, D. (2008). Hepatoprotective activity of aerial parts o Cynodon dactylon against CCl4-induced in rats. J Pharmacogn Mag, 4(16), 195-201.

Tammu, J., Ramana, K. V., \& Thalla, S. (2013). Antiulcer Activity of Methanolic Extract of Physalis minima Leaves. Int. J. PharmTech Res, 5(2). doi:10.1080/14756360802321120.

Tarhan, L., Kayali, H., \& Raziye, O. U. (2007). In Vitro Antioxidant Properties of Cucurbita pepo L. Male and Female Flowers Extracts Plant Foods for Human Nutrition., 62, 49-51. doi:10.1007/s11130-006-0038-0.

Teixeira, C. C., Knijnik, J., Pereira, M. V., \& Fuchs, F. D. (1989). The effect of tea prepared from leaves of "jambolao"(Syzygium cumini) on the blood glucose levels of normal rats an exploratory study. In Proceedings of the Brazilian-Sino Symposium on Chemistry and Pharmacology of Natural Products, Rio de Janeiro Brazil (p. 191) GOTTLIEB, O. (1991).

The Ayurvedic Pharmacopoeia of India. Part 1 (Vol. 3, 1st ed.p. 153). India: Government of India.

The wealth of India. (2004). "A dictionary of Indian raw material \& industrial products" raw material (Vol. 1). New Delhi: Publication \& Information Directorate.

The wealth of India. (1992). A raw material (Vol. 3, pp. 368-370). New Delhi: Council of Scientific and Industrial Research.

Thebtaranonth, C., Thebtaranonth, Y., Wanauppathamkul, S., \& Yuthavong, Y. (1995). Antimalarial sesquiterpenes from tubers of Cyperus rotundus: structure of 10, 12-peroxycalamenene, a sesquiterpene endoperoxide. Phytochemistry, 40(1), 125-128. doi:10.1016/0031-9422(95)00260-E.

Tuse, T. A., Harle, U. N., \& Bore, V. V. (2009). Hepatoprotective activity of Colocasiaantiquorum against experimentally induced liver injury in rats. Malyasian J Pharma Sci, 7(2), 99-112. http://web.usm.my/mjps/mjps07022009/ mjps07022009_2.pdf. Accessed 23 Dec 2015.

Udayan, P. S., Tushar, K. V., George, S., \& Balachandran, I. (2007). Ethnomedicinal information from Kattunayakas tribes of Mudumalai wildlife sanctuary, Nilgiris district, Tamil Nadu. Indian Journal of Traditional Knowledge, 6(4), 574-578. http://nopr.niscair.res.in/bitstream/123456789/1003/1/IJTK\%206(4)\%20(2007)\%20574-578.pdf. Accessed 20 Dec 2015.

Uddin, S. J., Mondal, K., Shilpi, J. A., \& Rahman, M. T. (2006a). Antidiarrhoeal activity of Cyperus rotundus. Fitoterapia, 77(2), 134-136. doi:10.1016/j.fitote.2004.11.011.

Uddin, S. J., Mondal, K., Shilpi, J. A., \& Rahman, M. T. (2006b). Antidiarrhoeal activity of Cyperus rotundus. Fitoterapia, 77(2), 134-136. doi:10.1016/j.fitote.2004.11.011.

Umadevi, M., Maheswari, C., Jothi, R., Paleti, S. K., Reddy, Y. S., \& Narayanan, R. V. (2011). Hepatoprotective Activity of Flowers of Madhuca longifolia (Koen.) Macbr. Against Paracetamol-Induced Hepatotoxicity. Research Journal of Pharmacy and Technology, 4(2), 259-262. Online ISSN: 0974-360X.

Umamaheswari, M., \& Chatterjee, T. K. (2008). In vitro antioxidant activities of the fractions of Coccinia grandis L. leaf extract. African Journal of Traditional, Complementary, and Alternative Medicines, 5(1), 61-73. ISSN: 0189-6016. 
Umerie, S. C., \& Ezeuzo, H. O. (2000). Physicochemical characterization and utilization of Cyperus rotundus starch. Bioresource Technology, 72(2), 193-196. doi:10.1016/S0960-8524(99)00103-0.

Unander, D. W., Webster, G. L., \& Blumberg, B. S. (1995). Usage and bioassays in Phyllanthus (Euphorbiaceae). IV. Clustering of antiviral uses and other effects. Journal of Ethnopharmacology, 45(1), 1-18. doi:10.1016/03788741(94)01189-7.

Vaghasiya, Y., \& Chanda, S. (2009). Screening of some traditionally used Indian plants for antibacterial activity against Klebsiella pneumonia. J Herb Med Toxicol, 3(2), 161-164. ISSN: 0973-4643.

Vaidyanathan, D., Senthilkumar, M. S., \& Basha, M. G. (2013). Studies on ethnomedicinal plants used by malayali tribals in Kolli hills of Eastern ghats, Tamilnadu, India. Asian Journal of Plant Science and Research, 3, 29-45. ISSN: 2249-7412. Accessed at https://www.researchgate.net/profile/M_Ghouse_Basha/publication/265794736_Studies_on_ ethnomedicinal_plants_used_by_Malayali_Gounder_Tribes_in_Pachamalai_of_Eastern_ghats_Tamil_Nadu_India/links/ 54faa2a20cf2040df21c5d2d.pdf

Van Valkenburg, J. L. C. H., \& Bunyapraphatsara, N. (2001). Plant Resources in South-East Asia (Vol. 12). Leiden: Backhuys Publishers.

Vidal, J. E. (1963). Les Plantes utiles du Laos: Cryptogames, gymnospermes, Monocotylédones. Muséum national d'histoire naturelle. Journal d'Agriculture tropicale et de Botanique appliquée, 1963, 320-325.

Vijaya Kumar, S., Sankar, P., \& Varatharajan, R. (2009). Anti-inflammatory activity of roots of Achyranthes aspera. Pharmaceutical Biology, 47(10), 973-975. doi:10.1080/13880200902967979.

Villasenor, I. M., Cabrera, M. A., Meneses, K. B., Rivera, V. R., \& Villasenor, R. M. (1998). Comparative antidiabetic activities of some medicinal plants. The Philippine Journal of Science, 127, 261-266.

Weber, L. W., Boll, M., \& Stampfl, A. (2003). Hepatotoxicity and mechanism of action of haloalkanes: carbon tetrachloride as a toxicological model. Critical Reviews in Toxicology, 33(2), 105-136. doi:10.1080/713611034.

Yadav, J. P., Kumar, S., \& Siwach, P. (2006). Folk medicine used in gynecological and other related problems by rural population of Haryana. Indian Journal of Traditional Knowledge, 5(3), 323-326.

Yun, J. (2017). Benefits and Costs of Closed Innovation Strategy: Analysis of Samsung's Galaxy Note 7 Explosion and Withdrawal Scandal, keynote lecture at SOItmC \& Riga Technical University 2017 Conference.

Yasmin, H., Kaisar, M. A., Sarker, M. M. R., Rahman, M. S., \& Rashid, M. A. (2009). Preliminary Anti-bacterial Activity of Some Indigenous Plants of Bangladesh. Dhaka Univ J Pharm Sci, 8, 61-65.

Yoganarasimhan, S. N. (1996). Medicinal plants of India (Vol. 1, p. 135). Bangalore: Interline publishers.

Yunus, M. (2010). June 15, Forbes India, https://www.forbes.com/2010/06/15/forbes-india-muhammad-yunus-socialbusiness-opinions-ideas-10-yunus.html. Accessed 1 June 2017.

Yusuf, M., Chowdhury, J. U., Wahab, M. A., \& Begum, J. (1994). Medical Plants of Bangladesh, Bangladesh Council of Scientific and Industrial Research (p. 73). Dhaka: Chittagong Laboratory.

Zaheer, Z., Shafique, S., Shafique, S., \& Mehmood, T. (2012). Antifungal potential of Parthenium hysterophorus L. plant extracts against Fusarium solani. Scientific Research and Essays, 7(22), 2049-2054. doi:10.5897/SRE12.082. . http:// www.academicjournals.org/journal/SRE/article-full-text-pdf/7357DFC34230. Accessed 8 Dec 2015.

Zahir, A. A., Rahuman, A. A., Kamaraj, C., Bagavan, A., Elango, G., Sangaran, A., \& Kumar, B. S. (2009). Laboratory determination of efficacy of indigenous plant extracts for parasites control. Parasitology Research, 105(2), 453-461. doi:10.1007/s00436-009-1405-1.

Zakaria, Z. A., Wen, L. Y., Abdul Rahman, N. I., Abdul Ayub, A. H., Sulaiman, M. R., \& Gopalan, H. K. (2007). Antinociceptive, anti-inflammatory and antipyretic properties of the aqueous extract of Bauhinia purpurea leaves in experimental animals. Medical Principles and Practice, 16(6), 443-449.

Zakaria, Z. A., et al. (2011). In vivo antiulcer activity of the aqueous extract of Bauhinia purpurea leaf. Journal of Ethnopharmacology, 137.2, 1047-1054.

Zereen, A., Bokhari, T. Z., \& Khan, Z.-U.-D. (2013). Ethnobotanical Usages of Grasses in Central Punjab-Pakistan. International Journal of Scientific \& Engineering Research, 4(9). https:/www.researchgate.net/profile/G_ LEELAPRAKASH/publication/215806094_Invitro_antimicrobial_and_antioxidant_activity_of_Momordica_charantia_ leaves/links/04325252bbcfedaeb9857001.pdf. Accessed 17 Dec 2015.

\section{Submit your manuscript to a SpringerOpen ${ }^{\circ}$ journal and benefit from:}

- Convenient online submission

- Rigorous peer review

Open access: articles freely available online

- High visibility within the field

- Retaining the copyright to your article

Submit your next manuscript at $\gg$ springeropen.com 